\title{
Исследование психологических и генетических различий у представителей разных этносов Юга России
}

\author{
Елена В. Воробьева ${ }^{1 *}$, Екатерина М. Ковш ${ }^{1,2}$, Павел Н. Ермаков², \\ Ирина В. Абакумова', Анжелика И. Лучинкина ${ }^{3}$, Елена Ю. Кольчик ${ }^{3}$, \\ Евгений Ф. Бороховский ${ }^{4}$ \\ ${ }^{1}$ Донской государственный технический университет, г. Ростов-на-Дону, \\ Российская Федерация \\ 2 Южный федеральный университет, г. Ростов-на-Дону, Российская Федерация \\ ${ }^{3}$ Крымский инженерно-педагогический университет, г. Симферополь, Российская \\ Федерация \\ 4 Университет Конкордия, г. Монреаль, Канада \\ *E-mail: evorob2012@yandex.ru
}

\section{Аннотация}

Введение. В работе приводятся результаты исслеАОвания психологических размичий в проявлении агрессивных установок и личностных особенностей, а также генетических различий по полиморфизму Val158Mеt гена СОМТ у представителей различных этносов, проживающих на Юге России. Новизна исследования состоит в том, что впервые были получены результаты оценки выраженности агрессивных Установок и личностных особенностей у зАоровых носителей разных генотипов гена СОМТ с учетом этнической приналлежности, впервые получены нормативные показатели по шкалам «Hand-test» Э. Вагнера А^я южнороссийской выборки.

Методы. В работе использовались: Шкала тревоги Спилбергера-Ханина, опросник формально-Аинамических свойств инАивиАуальности В. М. Русалова, «Hand-test» Э. Вагнера в алаптации Т. Н. Курбатовой. Генетический анализ: вылеление АНК из клеток буккального эпителия, полимеразная цепная реакция (ПЦР). В психо^огическом исследовании приняли участие 163 человека (студенты, среАний возраст 18,9 ^ет), в психогенетическом исслеАовании - 76 респондентов-жителей Крыма (57 женщин и 19 мужчин).

Результаты. Исследование показало наличие достоверно более высокого суммарного показателя агрессивности и Аирективности у преАставителей русской и татарской этнических групп с генотипами Met/Met гена COMT, нaряду с более высоким уровнем личностной тревожности и низкой моторной эргичностью. Наличие генотипа Val/Val гена COMT у девушек - этнических татарок связано с наличием такой психологической особенности, как Аемонстративность. Наличие генотипа $\mathrm{Val} / \mathrm{Met}$ гена СОМт у девушек - этнических русских связано с проявлением у них 


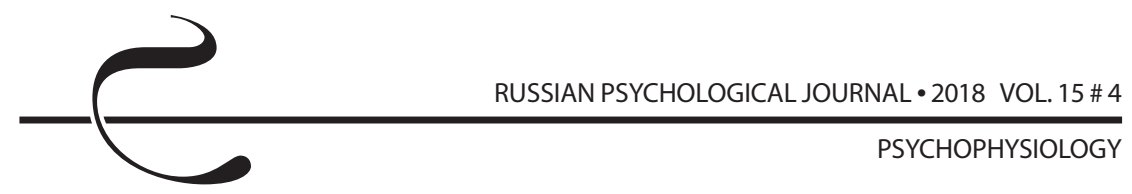

таких ^ичностных особенностей, как напряжение (тревога) и «психопатология», оцениваемая как суммарный показатель «степени личностной Аезалаптации» и «тенАенции к ухоАу от реальности».

ОбсужАение результатов. Полученные результаты могут найти применение в разработке направлений инАивиАуализации социально-пеАагогических возАействий на обладателей генотипов, ассоциированных в разных этнических группах с АезаАаптивными личностными характеристиками.

\section{КАючевые слова}

агрессивность, Аирективность, Аичностные особенности, этносы, полимороризм Val158Met, ген COMT, «Hand-test» Э. Вагнера, ^ичностная тревожность, эргичность, п^астичность

\section{Основные положения}

- выявлены психологические и генетические различия у представителей этносов Юга России - татар и русских;

- различия в проявлении суммарного показателя агрессивности и Аирективности (по метолике «Hand-†еst») у представителей русской и татарской этнических групп ассоциированы с наличием у них генотипа Met/Met по полиморсризму Val158Mеt гена СОМТ, кодирующего фрермент катехол-О-метилтрансфреразу;

- генотип Val/Val по полиморфииму Val158Mеt гена COMт у Аевушек - этнических татарок ассоциирован с такими психологическими особенностями, как склонность к самовыражению и самопрезентации;

- гетерозиготный генотип Val/Met по полиморфизму Val158Met гена COMT у Аевушек - этнических русских ассоциирован с проявлением у них личностных черт напряжения (тревоги) и «психопатологии», проявляющейся как суммарный показатель «степени личностной АезаАаптации» и «тенАенции к ухоАу от реальности».

\section{Для цитирования}

Воробьева Е. В., Ковш Е. М., Ермаков П. Н., Абакумова И. В., Лучинкина А. И., Кольчик Е. Ю., Бороховский Е. Ф. Исследование психологических и генетических различий у представителей разных этносов Юга России // Российский психологический журнал. 2018. T. 15, № 4. C. 206-244. DOI: 10.21702/rpj.2018.4.9

Материалы статьи получены 15.11.2018 


\title{
Psychological and Genetic Differences Among Representatives of Various Ethnic Groups Living in South Russia
}

\author{
Elena V. Vorobyeva ${ }^{1 *}$, Ekaterina M. Kovsh ${ }^{1,2}$, Pavel N. Ermakov ${ }^{2}$, Irina V. Abakumova', \\ Anzhelika I. Luchinkina ${ }^{3}$, Elena Yu. Kol'chik ${ }^{3}$, Eugene Borokhovski ${ }^{4}$ \\ ${ }^{1}$ Don State Technical University, Rostov-on-Don, Russian Federation \\ ${ }^{2}$ Southern Federal University, Rostov-on-Don, Russian Federation \\ ${ }^{3}$ Crimean Engineering Pedagogical University, Simferopol, Russian Federation \\ ${ }^{4}$ Concordia University, Montreal, Canada \\ *Corresponding author. E-mail: evorob2012@yandex.ru
}

\begin{abstract}
Introduction. This paper (a) presents the study of psychological differences in manifestations of aggressive attitudes and personal characteristics among representatives of various ethnic groups living in South Russia and (b) concentrates on genetic differences in the COMT Val158Met polymorphism within the study sample. This is the first study that (a) has assessed manifestations of aggressive attitudes and personal characteristics in healthy representatives of various ethnic groups with different COMT genotypes and (b) has offered normative data for the Wagner Hand Test obtained from an investigation in a sample of South Russian individual participants.
\end{abstract}

Methods. The study used the following techniques: (a) the Spielberger-Hanin anxiety test, (b) the questionnaire of formal-dynamic characteristics of personality by Rusalov, and (c) the Wagner Hand Test (in Kurbatova's modification). Genetic analysis included the method for DNA extraction from buccal epithelial cells and the polymerase chain reaction (PCR) method. The psychological study involved university students ( $n=163$; mean age, 18.9 years); the psychogenetic study involved residents of Crimea ( $n=76$; 57 women and 19 men).

Results. The representatives of Russian and Tatar ethnic groups with the Met/Met COMT genotype had significantly higher total scores of aggression and direction, higher level of trait anxiety, and low motor ergicity. Tatar girls from the Val/Val COMT genotype group had high scores in the exhibitionism scale. The Val/Met COMT genotype in Russian girls was associated with manifestations of tension (anxiety) and 'pathology' as a total index of 'personal maladjustment' and the 'tendency to escape from reality'.

Discussion. The obtained results can be applied to the practice of individualized socio-pedagogical impacts on representatives of various ethnic groups with the genotypes associated with maladaptive personality traits. 


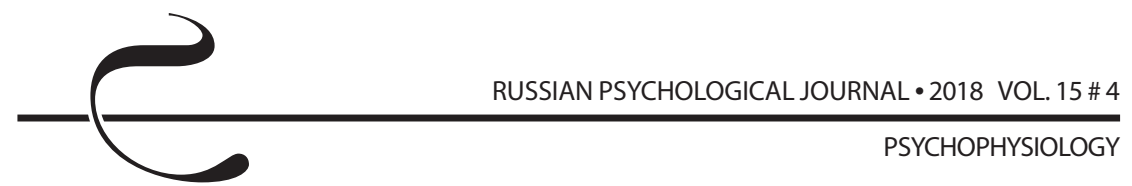

\section{Keywords}

aggression, direction, personal characteristics, ethnic groups, Val158Met polymorphism, COMT gene, Wagner Hand Test, trait anxiety, ergicity, plasticity

\section{Highlights}

- This study identified psychological and genetic differences among representatives of Tatar and Russian ethnic groups living in South Russia.

- The Met/Met COMT genotype is associated with differences in total scores of aggression and direction (in the Wagner Hand Test) among representatives of Russian and Tatar ethnic groups.

- The Val/Val COMT genotype is associated with self-expression and self-presentation in Tatar girls.

- Russian girls bearing the Val/Met heterozygous genotype are characterized by manifestations of tension (anxiety) and 'pathology' as a total index of 'personal maladjustment' and the 'tendency to escape from reality'.

\section{For citation}

Vorobyeva E. V., Kovsh E. M., Ermakov P. N., Abakumova I. V., Luchinkina A. I., Kol'chik E. Yu., Borokhovski E. Psychological and Genetic Differences Among Representatives of Various Ethnic Groups Living in South Russia. Rossiiskii psikhologicheskii zhurnal-Russian Psychological Journal, 2018, V. 15, no. 4, pp. 206-244 (in Russian). DOI: 10.21702/rpj.2018.4.9

Original manuscript received 15.11.2018

\section{Введение}

Современный Юг России - полиэтнический регион; на его территории проживает множество этносов, каждый из которых имеет как культурно-средовые, так и генетические особенности, что делает необходимым проведение междисциплинарных исследований, направленных на более эффективное межэтническое понимание и взаимодействие. В данной статье представлены результаты одной из таких работ, выполненных в Республике Крым с привлечением представителей различных этносов, проживающих в г. Симферополе. Как отмечается, «полиэтничность и многоконфессиональность Крыма, стоящие перед ним задачи в настоящих реалиях делают проблему сохранения собственных этносов и эффективное взаимодействие с другими народами особенно актуальной» [1, с. 122].

В последнее время в генетике поведения сформировались представления о сложных процессах взаимодействия генотипа и среды, которые предусматривают как воздействие среды на экспрессию генов (эпигенетика), так 
и воздействие генов на реализуемый индивидом поиск подходящей для их реализации среды (генотип-средовая ковариация) [2].

Ген СОМТ, связанный с работой дофаминовой нейромедиаторной системы мозга, кодирует фермент катехол-О-метилтрансферазу, который разрушает дофамин, норадреналин и адреналин. Ген СОМТ, а именно его полиморфизм Val158Met, рассматривается как ассоциированный с уровнем агрессивности и враждебности $[3,4,5,6]$. Показано, что у носителей генотипа Val/Val наиболее низкий уровень дофамина, поскольку его обратный захват из синаптической щели происходит весьма быстро, и такие люди в ситуации фрустрации склонны проявлять агрессию. У носителей генотипа Met/Met, напротив, уровень дофамина наиболее высок, т. к. его обратный захват реализуется медленнее, чем у носителей генотипа Val/Val, а в ситуации фрустрации носители генотипа Met/Met склонны к проявлению тревоги. Обладатели гетерозиготного генотипа Val/Met по уровню дофамина и скорости его обратного захвата занимают промежуточную позицию $[7,8]$. Также было установлено, что носители двух аллелей Val проявляют более низкий уровень агрессивного поведения в ответ на физическую агрессию, а также имеют более позитивные отношения с родителями, чем носители аллеля Met [9]. В то же время, наличие аллеля Met у взрослых носителей связано с лучшей организацией и снижением активации префронтальной коры головного мозга во время решения задач, задействующих рабочую память [10].

В наших более ранних работах также был проведен анализ ассоциаций различных генотипов по гену СОМТ с психологическими особенностями у представителей различных этносов [11, 12].

В последнее десятилетие в качестве опосредующего звена между геном и его предполагаемым проявлением в фенотипе, особенно когда речь идет о сложных психологических особенностях, применяется оценка эндофенотипов как более упрощенных, промежуточных характеристик [13].

Уровень агрессивности может быть детерминирован не только генетическими факторами, но и определяться также средовыми влияниями, такими, например, как усвоение в детстве привычных способов поведения в семье, посредством идентификации ребенка с родителем одного с ним пола. Так, в работе M. R. A. Muscatello и др. было показано, что молодые люди с высокими показателями агрессивности по «Hand-test» Э. Вагнера имеют отцов с высокими показателями агрессивности по этому тесту, однако показатели агрессивности отцов ниже, чем показатели агрессивности сыновей [14].

В качестве возможных каналов закрепления агрессивных форм поведения у молодежи отмечается влияние средств массовой информации, фильмов с агрессивным содержанием, преподносящих молодежи агрессивные способы поведения как единственно верные [15]. 


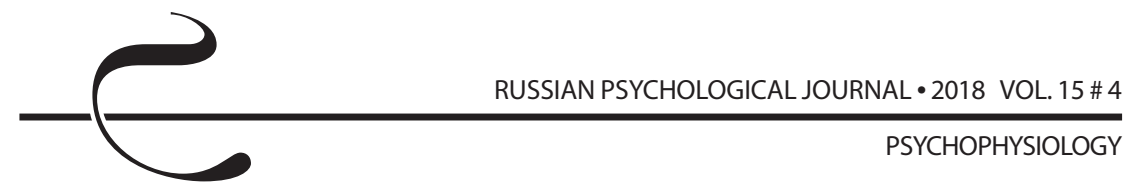

Также среди средовых факторов, обуславливающих агрессивное поведение, выделяют фрустрацию базовых потребностей личности, например такой, как потребность в безопасности [16]. Хорошо известны ситуации, провоцирующие проявление повышенной агрессивности у людей в переполненном общественном транспорте, водителей на дороге и др. [17]. В то же время, изменение социальной среды может провоцировать как рост, так и снижение уровня агрессивных проявлений [18].

Маскирующими и нивелирующими факторами по отношению к проявлениям агрессивного поведения часто выступают усвоенные через воспитание социальные нормы поведения, страх наказания, перевод агрессивных импульсов в занятия спортом и другую социально-приемлемую и одобряемую деятельность [19]. В то же время, во многих жизненных ситуациях просто необходимо выразить свое негативное отношение к чему-либо или кому-либо, отстоять свою точку зрения, оставляя и за партнерами по общению право на выражение своего недовольства, несогласия или непринятия [20]. В данном случае агрессия проявляется человеком для отстаивания психологических границ и имеет целью не допустить нанесение ущерба собственной личности.

Важное место в воспитании межэтнического взаимопонимания в условиях поликультурных регионов принадлежит формированию полиэтнической компетентности [21]. В этой связи продуктивным подходом представляется изучение ведущих ценностных ориентаций молодежи различной этноконфессиональной принадлежности и формирование толерантности в межэтническом общении $[22,23,24]$.

Следует отметить, что психологическая диагностика склонности к агрессивному поведению может быть наиболее информативна и достоверна в случае использования проективных методик, поскольку при заполнении тестов-опросников обследуемые, понимая, каких именно аспектов поведения касаются формулировки вопросов, стараются отвечать на них, исходя из собственных представлений о социально-желаемом поведении, внося мотивационные искажения в результаты тестирования [25].

Проективная методика «Hand-test» Э. Вагнера используется для определения показателей агрессивности, директивности в поведении, с одной стороны и, с другой стороны, баланса суммарного показателя агрессивно-директивного поведения и выраженности установок на позитивное взаимодействие, общение и эмоциональное принятие. Согласно Э. Вагнеру, агрессивность предполагает намеренность действий (в отличие от случайности), применение насилия, наличие телесных повреждений или негативных последствий для потерпевших [26].

«Hand-test» Э. Вагнера нашел применение в психиатрической практике при оценке риска агрессии у больных, находящихся на принудительном 
лечении (в ходе подготовки к их выписке), у больных с различными психическими расстройствами (шизофрения, шизоаффективное расстройство, аффективная патология - биполярное расстройство, личностное расстройство), а также у больных рассеянным склерозом [27, 28]. Распространено применение «Hand-test» Э. Вагнера в нашей стране в ходе судебной психолого-психиатрической экспертизы, в ходе которой тест применяется для оценки уровня агрессивности респондентов [29]. В работе психологических служб в системе образования «Hand-test» Э. Вагнера применяется при работе с подростками и молодежью для выявления склонности к агрессивному поведению и других особенностей личности [26].

Целью данного исследования явилось изучение агрессивных установок и личностных особенностей у носителей различных генотипов по полиморфизму Val158Met гена СОМТ, проживающих на Юге России (Крым).

Предметом исследования явились: агрессивные установки и личностные особенности, проявляющиеся в результате продуцирования ассоциаций при выполнении «Hand-test» Э. Вагнера; уровень ситуативной и личностной тревожности; формально-динамические свойства индивидуальности у здоровых носителей различных генотипов по полиморфизму Val158Met гена COMT.

Объект исследования: жители Юга России (Крыма), носители различных генотипов гена СОМТ с разной этнической принадлежностью.

Гипотеза исследования: вероятно, генотипы Val/Val, Val/Met и Met/Met по полиморфизму Val158Met гена СОМТ ассоциированы с определенными агрессивными установками и личностными особенностями, формально-динамическими свойствами индивидуальности, уровнем ситуативной и личностной тревожности у жителей Юга России (Крыма) с разной этнической принадлежностью.

\section{Методы}

Общее количество респондентов, принявших участие в психологическом тестировании, составило 163 человека (студенты, средний возраст 18,9 лет). Среди них русских - 74 человека, татар - 68 человек, украинцев - 14 человек, чувашей - 1 человек, 6 человек не указали свою этническую принадлежность. Половой состав выборки был представлен 127 женщинами и 36 мужчинами.

В психогенетическом исследовании приняли участие 76 респондентов жителей Крыма (57 женщин и 19 мужчин). Из них татар - 45 человек, русских 31 человек. По гену СОМT - 22 носителя генотипа Val/Nal, 26 носителей генотипа $\mathrm{Val} / \mathrm{Met}, 28$ носителей генотипа Met/Met.

Генетический анализ: выделение ДНК из клеток буккального эпителия, генотипирование методом полимеразной цепной реакции (ПЦР) (ООО «Биологические решения и технологии», г. Москва, Россия). 
Психодиагностические методики: шкала тревоги Спилбергера - Ханина, опросник формально-динамических свойств индивидуальности В. М. Русалова, «Hand-test» Э. Вагнера в адаптации Т. Н. Курбатовой.

Шкала тревоги Ч. Д. Спилбергера (State-Trait Anxiety Inventory-STAI) позволяет провести самооценку уровня реактивной (в связи с текущими актуальными событиями) и личностной тревожности (как устойчивой характеристики). Шкала адаптирована Ю. Л. Ханиным [30].

Опросник формально-динамических свойств индивидуальности В. М. Русалова (ОФДСИ) включает показатели эргичности, пластичности, скорости и эмоциональности (с выделением по каждой из них психомоторной, интеллектуальной и коммуникативной шкал) и контрольную шкалу [31].

Стимульный материал «Hand-test» Э. Вагнера состоит из девяти карточек со стандартным изображением кистей рук и одной пустой карточки. Десять карточек предъявляются обследуемому в определенной последовательности, при этом регистрируется время от начала предъявления карточки до начала ассоциативного процесса у обследуемого (время реакции). При обработке полученных данных каждой ассоциации присваивается категория: Agg - агрессивность, Dir - директивность, Aff - аффектация (эмоциональность), Com - коммуникация, Dep - зависимость, F - страх, Еx - эксгибиционизм, демонстративность, Crip - «калечность», Des - описание руки, Ten - напряжение, Act-активное безличное действие, Pas - пассивное безличное действие, Bas галлюцинации, Fail - отказ. После подсчета суммарного количества ассоциаций той или иной категории производится определение следующих показателей: I- склонность к агрессивному поведению (с «+»- есть склонность, с «-» - нет склонности) $(\mathrm{I}=(\mathrm{Agg}+\mathrm{Dir})-(\mathrm{Aff}+\mathrm{Com}+\mathrm{Dep})), \mathrm{MAL}-$ степень личностной дезадаптации (MAL = Ten + Crip + F), WITH - тенденция к уходу от реальности (WITH = Des + Bas + Fail), PATH - наличие психопатологии (PATH $=$ MAL + 2 WITH), $\Sigma$ отв.- общее количество ответов [32].

Для статистической обработки полученных результатов были использованы дескриптивный анализ, многофакторный дисперсионный анализ ANOVA (независимые переменные - «генотип» и «этническая принадлежность»), Post-Hoc анализ Фишера, $p \leq 0,05$.

\section{Результаты}

Дескриптивный анализ полученных данных no «Hand-test» Э. Вагнера

В таблице 1 приведены результаты диагностики всей выборки, принимавшей участие в исследовании, с применением «Hand-test» (таблица 1). Среднегрупповые значения, а также стандартные отклонения близки к приводимым нормативным показателям [33]. 


\begin{tabular}{|c|c|c|c|c|c|c|}
\hline & $\overline{0}$ & \multirow{15}{*}{ 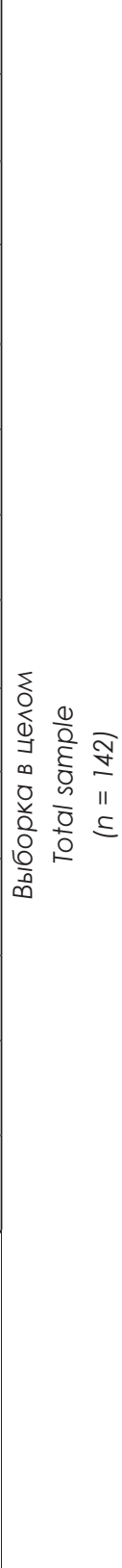 } & $\stackrel{2}{2}$ & సิ & $\frac{a}{\sigma}$ & $\begin{array}{l}\hat{\sigma} \\
\hat{o}\end{array}$ \\
\hline & 今. & & 号 & $\stackrel{+}{\stackrel{t}{O}}$ & $\frac{a}{\sigma}$ & 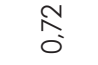 \\
\hline & z̆ & & ? & $\begin{array}{l}a \\
\text { of } \\
0\end{array}$ & $\stackrel{?}{=}$ & 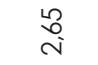 \\
\hline & $\bar{\psi}$ & & $\stackrel{8}{\stackrel{8}{=}}$ & $\frac{20}{60}$ & $\begin{array}{l}\bar{o} \\
\text { r }\end{array}$ & $\begin{array}{l}\text { ָे } \\
\text { in }\end{array}$ \\
\hline & 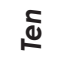 & & ơd & $\stackrel{2}{2}$ & 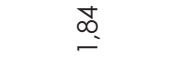 & $\frac{N}{m}$ \\
\hline & $\tilde{\Xi}$ & & 웅 & $\underset{O}{O}$ & $\underline{\underline{n}}$ & Oे \\
\hline & $\frac{2}{3}$ & & $\stackrel{\substack{0 \\
0}}{0}$ & 8 & 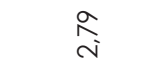 & $\stackrel{2}{\stackrel{2}{\sim}}$ \\
\hline & 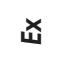 & & $\underline{\underline{m}}$ & f & 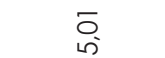 & 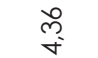 \\
\hline & 4 & & ô. & $\begin{array}{l}\infty \\
\stackrel{0}{0}\end{array}$ & $\stackrel{g}{g}$ & 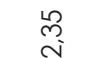 \\
\hline & $\frac{\circ}{8}$ & & $\frac{\infty}{0}$ & 守 & $\begin{array}{l}R \\
\text { O }\end{array}$ & $\stackrel{\text { 오 }}{=}$ \\
\hline & ฮั & & $\underset{\forall}{\stackrel{む}{\sigma}}$ & $\overline{\bar{N}}$ & $\begin{array}{l}\bar{\infty} \\
\stackrel{\rho}{\rho}\end{array}$ & 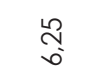 \\
\hline & 安 & & $\stackrel{\infty}{\stackrel{\sim}{ }}$ & $\stackrel{\stackrel{m}{m}}{=}$ & 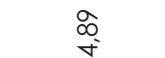 & $\begin{array}{l}\bar{f}_{f} \\
\end{array}$ \\
\hline סِ & 言 & & $\underset{\text { pे }}{\text { pे }}$ & $\stackrel{\circ}{=}$ & $\stackrel{\stackrel{2}{\sim}}{\stackrel{N}{\simeq}}$ & $\begin{array}{l}\text { त̂ } \\
\text { in }\end{array}$ \\
\hline ב⿱ & : & & ָั & $\stackrel{?}{\stackrel{2}{2}}$ & $\begin{array}{l}\text { ¿े } \\
\infty \\
\infty\end{array}$ & Si \\
\hline 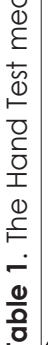 & 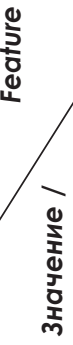 & & 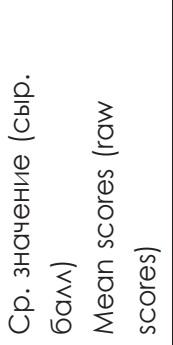 & 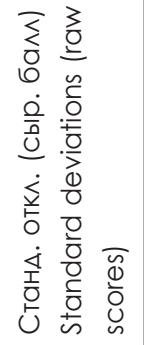 & 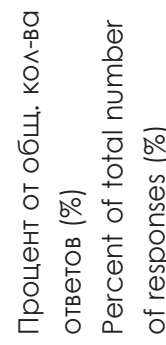 & 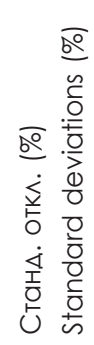 \\
\hline
\end{tabular}




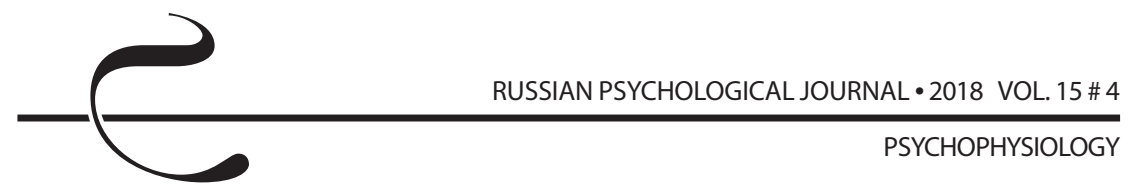

\begin{tabular}{|c|c|c|c|c|c|}
\hline$\overline{\overline{0}}$ & \multirow{15}{*}{ 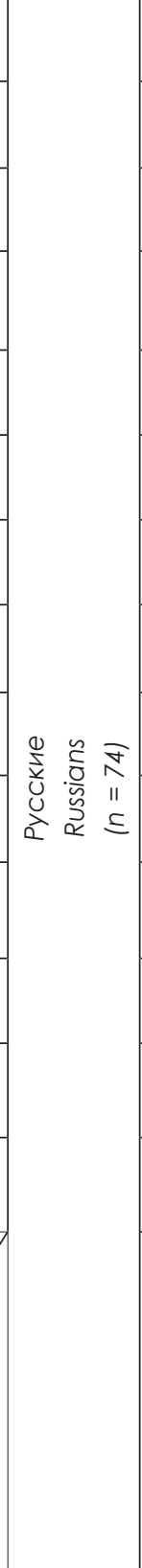 } & 1 & 1 & \& & ৪ \\
\hline$\stackrel{\text { o }}{0}$ & & ¿্口 & 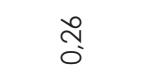 & $\frac{n}{0}$ & $\begin{array}{l}\stackrel{\circ}{\circ} \\
\stackrel{0}{0}\end{array}$ \\
\hline : & & 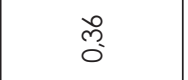 & 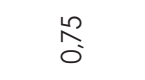 & 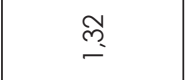 & $\underset{\sim}{\mathbb{N}}$ \\
\hline $\bar{t}$ & & $\stackrel{\infty}{\stackrel{\infty}{=}}$ & 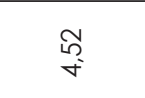 & $\begin{array}{l}\hat{0} \\
\stackrel{q}{q}\end{array}$ & 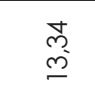 \\
\hline$\Subset$ & & $\begin{array}{l}\infty \\
0 \\
0\end{array}$ & $\stackrel{\text { p }}{\sim}$ & 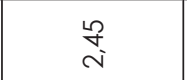 & 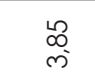 \\
\hline$\tilde{\Xi}$ & & 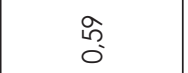 & $\stackrel{\text { m}}{\sim}$ & $\frac{n}{i}$ & $\stackrel{\nwarrow}{\underset{f}{*}}$ \\
\hline$\frac{2}{3}$ & & $\underset{0}{\hat{O}}$ & å & 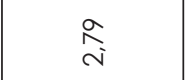 & 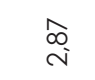 \\
\hline x & & $\stackrel{n}{n}$ & $\stackrel{\stackrel{R}{R}}{\longrightarrow}$ & 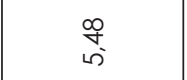 & $\underset{\substack{\bar{f} \\
\&}}{ }$ \\
\hline 4 & & đ̃ & $\stackrel{\infty}{\stackrel{\infty}{0}}$ & 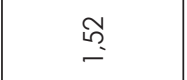 & $\underset{\sim}{\stackrel{\sim}{N}}$ \\
\hline ه & & $\frac{\infty}{\circ}$ & 尔 & $\begin{array}{l}\text { J } \\
\text { O }\end{array}$ & $\stackrel{m}{\stackrel{m}{-}}$ \\
\hline छे & & $\stackrel{\infty}{\stackrel{\infty}{\sim}}$ & $\frac{N}{N}$ & $\begin{array}{l}\text { న్ } \\
\text { กొ }\end{array}$ & 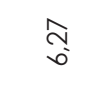 \\
\hline 安 & & $\stackrel{\text { p. }}{-}$ & 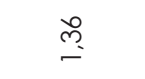 & $\underset{\sim}{\stackrel{R}{f}}$ & $\begin{array}{l}\mathscr{\sim} \\
\text { o }\end{array}$ \\
\hline $\bar{\partial}$ & & $\begin{array}{l}\hat{\omega} \\
\text { j) }\end{array}$ & $\stackrel{+}{-}$ & 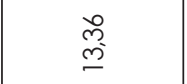 & $\begin{array}{c}\mathcal{F} \\
\text { is }\end{array}$ \\
\hline : & & $\underset{\mathbb{N}}{\mathbb{N}}$ & $\stackrel{?}{\longleftarrow}$ & $\begin{array}{l}\stackrel{\infty}{\infty} \\
\infty\end{array}$ & 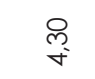 \\
\hline 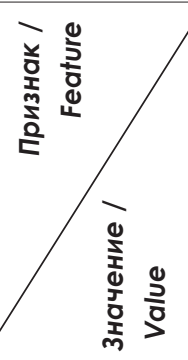 & & 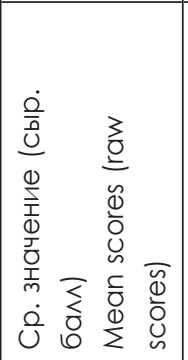 & 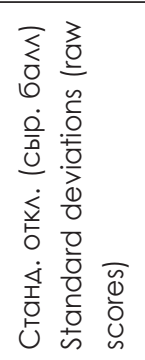 & 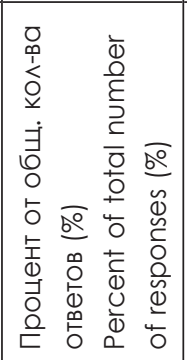 & 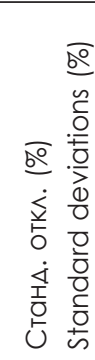 \\
\hline
\end{tabular}




\begin{tabular}{|c|c|c|c|c|c|}
\hline$\overline{\overline{0}}$ & \multirow{15}{*}{ 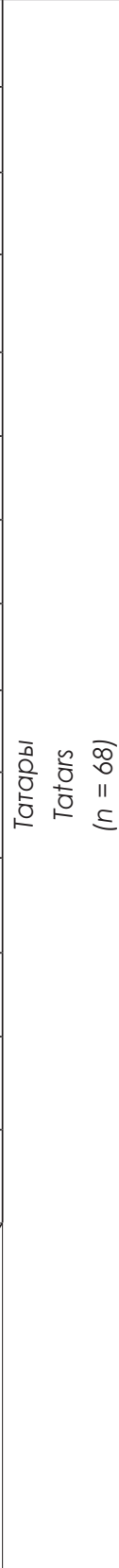 } & ô. & ō & $\begin{array}{l}\text { సे } \\
\text { o }\end{array}$ & $\begin{array}{l}\stackrel{2}{\alpha} \\
\stackrel{0}{0}\end{array}$ \\
\hline : & & ô & 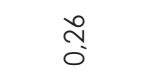 & ָे & $\stackrel{a}{\hat{a}}$ \\
\hline$\check{c}$ & & $\begin{array}{l}\text { 응 } \\
\circ\end{array}$ & $\stackrel{\infty}{\stackrel{\infty}{-}}$ & $\underset{\mathbb{Z}}{\sim}$ & 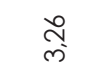 \\
\hline $\bar{\Psi}$ & & $\begin{array}{l}\text { 음 } \\
\text { ○ }\end{array}$ & $\stackrel{\sim}{\sim}$ & 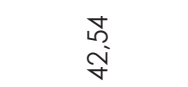 & $\begin{array}{l}\text { 品 } \\
\stackrel{\Delta}{L}\end{array}$ \\
\hline$\Subset$ & & 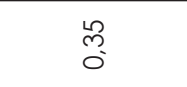 & $\begin{array}{l}\text { N } \\
\infty \\
0 \\
0\end{array}$ & $\stackrel{f}{-}$ & $\underset{\sim}{\stackrel{\sim}{d}}$ \\
\hline$\check{\Xi}$ & & $\stackrel{\stackrel{\sim}{~}}{0}$ & $\overline{0}$ & $\stackrel{8}{-}$ & $\stackrel{\infty}{\stackrel{\infty}{-}}$ \\
\hline$\frac{2}{3}$ & & $\underset{\hat{O}}{\mathbb{N}}$ & $\stackrel{o}{\circ}$ & 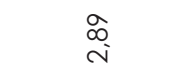 & $\underset{\text { ले }}{\stackrel{a}{n}}$ \\
\hline x & & $\stackrel{o}{\text { O }}$ & $\stackrel{\text { m }}{\sim}$ & $\underset{\sim}{\bar{\gamma}}$ & $\begin{array}{l}\infty \\
\stackrel{\infty}{\infty}\end{array}$ \\
\hline 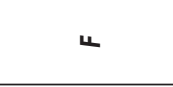 & & 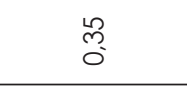 & 犬̂. & $\underset{\sim}{\stackrel{F}{-}}$ & $\stackrel{\widetilde{\sim}}{\sim}$ \\
\hline §̊ & & $\bar{ָ}$ & 艿 & $\begin{array}{l}m \\
0 \\
0 \\
0\end{array}$ & $\stackrel{\sigma o}{=}$ \\
\hline ฮे & & $\underset{\sim}{\text { o }}$ & $\bar{c}$ & $\begin{array}{l}= \\
0\end{array}$ & 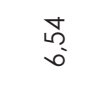 \\
\hline 安 & & $\stackrel{\circ}{\stackrel{R}{=}}$ & 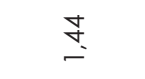 & ơ & $\underset{\sim}{\stackrel{\sim}{*}}$ \\
\hline ¿े & & $\bar{c}$ & 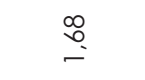 & 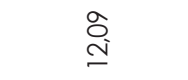 & $\begin{array}{l}\hat{0} \\
\text { in }\end{array}$ \\
\hline প্ & & $\frac{n}{i}$ & $\stackrel{\stackrel{2}{=}}{=}$ & $\begin{array}{l}\bar{\sigma} \\
\infty\end{array}$ & 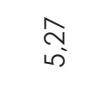 \\
\hline 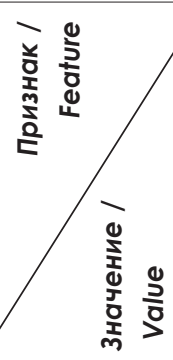 & & 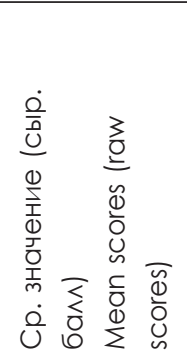 & 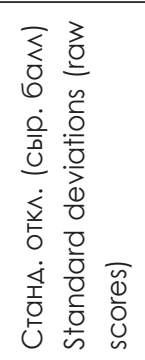 & 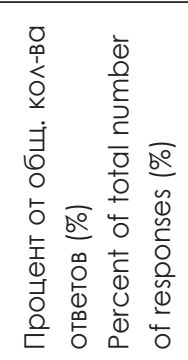 & 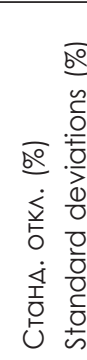 \\
\hline
\end{tabular}




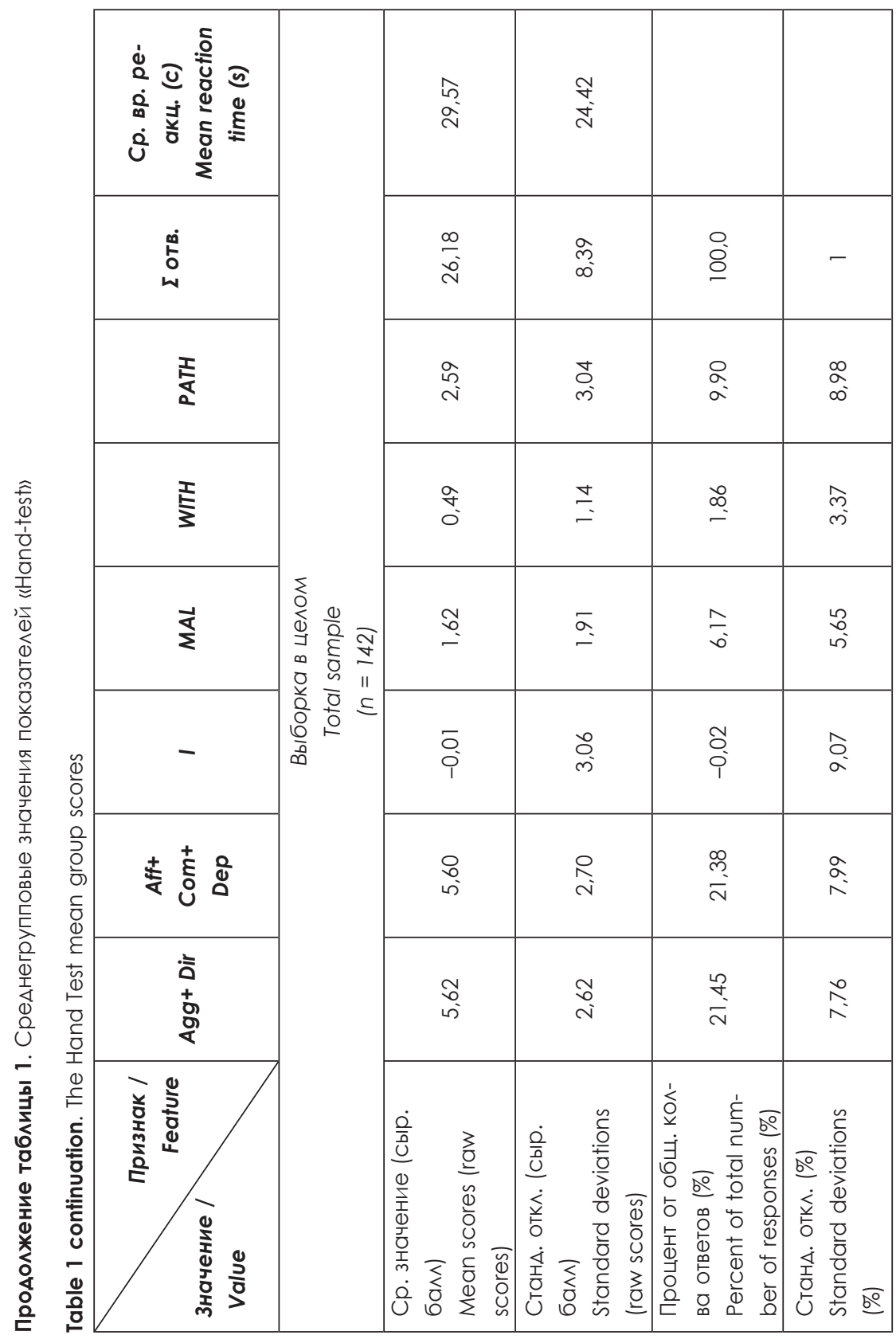




\begin{tabular}{|c|c|c|c|c|c|}
\hline 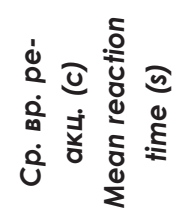 & \multirow{9}{*}{ 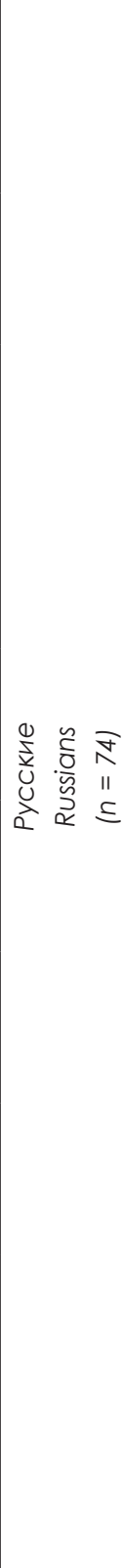 } & $\frac{\bar{c}}{\stackrel{\infty}{N}}$ & $\begin{array}{l}\bar{z} \\
\text { d }\end{array}$ & & \\
\hline $\begin{array}{l}\infty \\
5 \\
5 \\
w\end{array}$ & & $\begin{array}{l}\bar{\sim} \\
\stackrel{\sim}{2}\end{array}$ & $\stackrel{1}{\infty}$ & $\stackrel{\circ}{\circ}$ & $\begin{array}{l}\infty \\
\stackrel{\infty}{\sim}\end{array}$ \\
\hline$\frac{\mathrm{T}}{\mathrm{T}}$ & & $\underset{j}{\stackrel{g}{r}}$ & 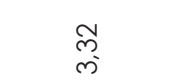 & $\underset{N}{\Xi}$ & $\frac{a}{a}$ \\
\hline 胥 & & $\begin{array}{l}\text { İ } \\
\text { Oे }\end{array}$ & $\underset{\Xi}{\stackrel{ \pm}{*}}$ & 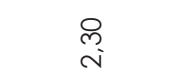 & $\stackrel{\stackrel{\sim}{\sim}}{\underset{\forall}{*}}$ \\
\hline$\sum$ & & $\stackrel{\sim}{\infty}$ & $\underset{\infty}{\stackrel{\infty}{-}}$ & రొ & $\begin{array}{l}\text { mे } \\
\text { in }\end{array}$ \\
\hline- & & $\frac{\infty}{0}$ & $\frac{n}{m}$ & $\begin{array}{l}\text { Z } \\
\text { Oे } \\
0\end{array}$ & ळે. \\
\hline 索䓂 & & 号 & 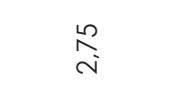 & $\begin{array}{l}\stackrel{0}{\infty} \\
\stackrel{i}{1}\end{array}$ & $\frac{1}{\infty}$ \\
\hline 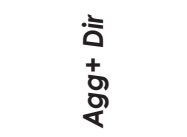 & & à & ô & 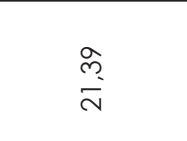 & 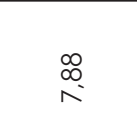 \\
\hline 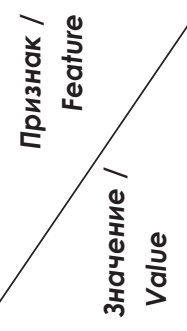 & & 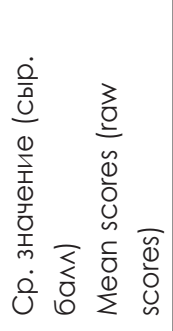 & 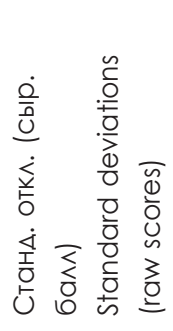 & 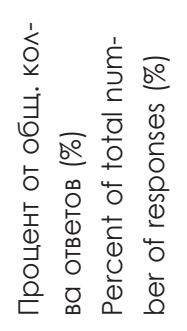 & 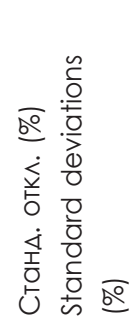 \\
\hline
\end{tabular}




\begin{tabular}{|c|c|c|c|c|c|}
\hline 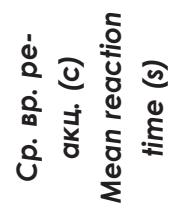 & & $\begin{array}{l}\text { 命 } \\
\text { o } \\
\text { N }\end{array}$ & 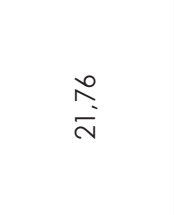 & & \\
\hline $\begin{array}{l}\infty \\
\stackrel{6}{\circ} \\
\text { w }\end{array}$ & & $\begin{array}{l}\text { a } \\
\stackrel{\sim}{d}\end{array}$ & $\begin{array}{l}\text { ले } \\
\infty\end{array}$ & 웅 & - \\
\hline$\frac{T}{\mathbb{2}}$ & & ָิ & 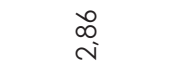 & $\begin{array}{l}\bar{\alpha} \\
\infty\end{array}$ & $\begin{array}{l}\text { तु } \\
\infty\end{array}$ \\
\hline 疍 & & 웅 & $\begin{array}{l}\stackrel{n}{\infty} \\
0 \\
0\end{array}$ & 恣 & iั \\
\hline$\stackrel{\vec{s}}{\Sigma}$ & $\overline{0} \cong \bar{\infty}$ & $\stackrel{\text { P }}{=}$ & $\stackrel{\text { ñ }}{\text { N }}$ & $\frac{N}{N}$ & $\frac{1}{0}$ \\
\hline- & & $\begin{array}{l}0 \\
0 \\
0 \\
1\end{array}$ & $\frac{N}{\alpha}$ & \begin{tabular}{l}
$n$ \\
0 \\
\multirow{1}{1}{} \\
1
\end{tabular} & $\begin{array}{l}\text { N } \\
\infty \\
\infty \\
\infty\end{array}$ \\
\hline 走 & & $\frac{N}{N}$ & $\begin{array}{l}N \\
\infty \\
\text { N }\end{array}$ & $\begin{array}{l}\text { ฉ } \\
\text { స̃ }\end{array}$ & $\begin{array}{l}\text { 目 } \\
\infty\end{array}$ \\
\hline ชั & & $\frac{n}{6}$ & مo & $\begin{array}{l}n \\
0 \\
0\end{array}$ & $\stackrel{n}{n}$ \\
\hline 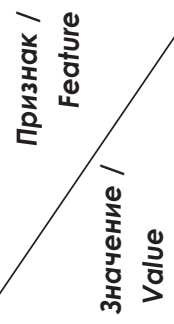 & & 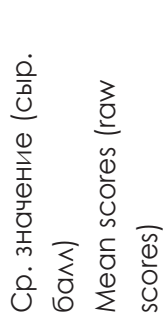 & 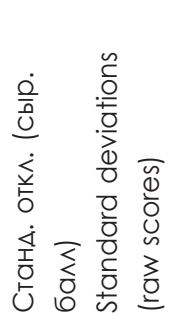 & 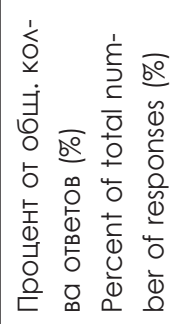 & 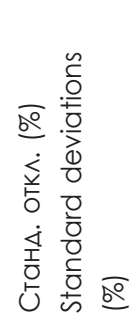 \\
\hline
\end{tabular}


Анализ таблицы 1 показывает, что нет статистически достоверных различий между выделенными группами (по этнической принадлежности) по показателям «Hand-test».

Анализ ассоциации генотипов гена СОМТ и проявлений личностной тревожности, а также формально-динамических свойств индивидуальности

Ниже приведены результаты только по тем показателям шкалы тревоги Спилбергера - Ханина и опросника формально-динамических свойств индивидуальности В. М. Русалова, по которым были получены статистически значимые результаты.

Согласно полученным результатам проведенного дисперсионного анализа ANOVA (зависимая переменная - показатель личностной тревожности по шкале тревоги Спилбергера - Ханина), у русских среднегрупповой уровень личностной тревожности выше, по сравнению с татарами. При этом генотип, ассоциированный с достоверно более высоким уровнем личностной тревожности в выборках татар и русских - Met/Met гена COMT (Mp $=50,8$, Mт = 53, $\mathrm{p}=0,02)$ (рисунок 1).

Изучение ассоциации генотипов гена СОМТ с формально-динамическими свойствами индивидуальности показало (зависимая переменная - показатель моторной эргичности по ОФДСИ В. М. Русалова), что генотип, ассоциированный с достоверно более низким уровнем моторной эргичности в выборках татар и русских - Met/Met гена СОМТ (Mp = 25,7, Мт =22,7, p=0,03) (рисунок 2).

В группе татар, согласно результатам дисперсионного анализа (зависимая переменная - показатель интеллектуальной эргичности по ОФДСИ В. М. Русалова) с достоверно более высоким показателем интеллектуальной пластичности связан генотип Met/Met $(M=30,7, p=0,03)$, с самым низким генотип Val/Met $(M=25,5, p=0,03)$ (рисунок 3).

\section{Анализ ассоциации генотипов гена СОМТ, агрессивных установок и черт личности, выявляемых с применением «Hand-test» Э. Вагнера}

Ниже приведены результаты только по тем категориям «Hand-test», по которым были получены статистически значимые результаты.

Согласно полученным результатам проведенного многофакторного дисперсионного анализа ANOVA (зависимая переменная - показатель демонстративности по «Hand-test» Э. Вагнера), наиболее выражен фактор демонстративности (стремление к самовыражению) у татар, носителей генотипа $\mathrm{Val} / \mathrm{Val}(\mathrm{M}=3,5, \mathrm{p}=0,001)$, русских, носителей генотипов Val/Val $(\mathrm{M}=2,3$, $\mathrm{p}=0,01)$ и Met/Met $(M=2, p=0,02)$, в то время как у представителей других групп данный фактор выражен достоверно в меньшей степени (рисунок 4). 
Достоверно чаще описывают руку, как имеющую различные увечья (зависимая переменная - показатель «калечности» (Crip) по «Hand-test» Э. Вагнера), татары, носители генотипа Val/Val (M=1,8, $\mathrm{p}=0,003)$, и русские, носители генотипа Met/Met $(M=1,1, p=0,02)$, в то время как представители других групп достоверно более редко используют в описании данную категорию ответов (рисунок 5).

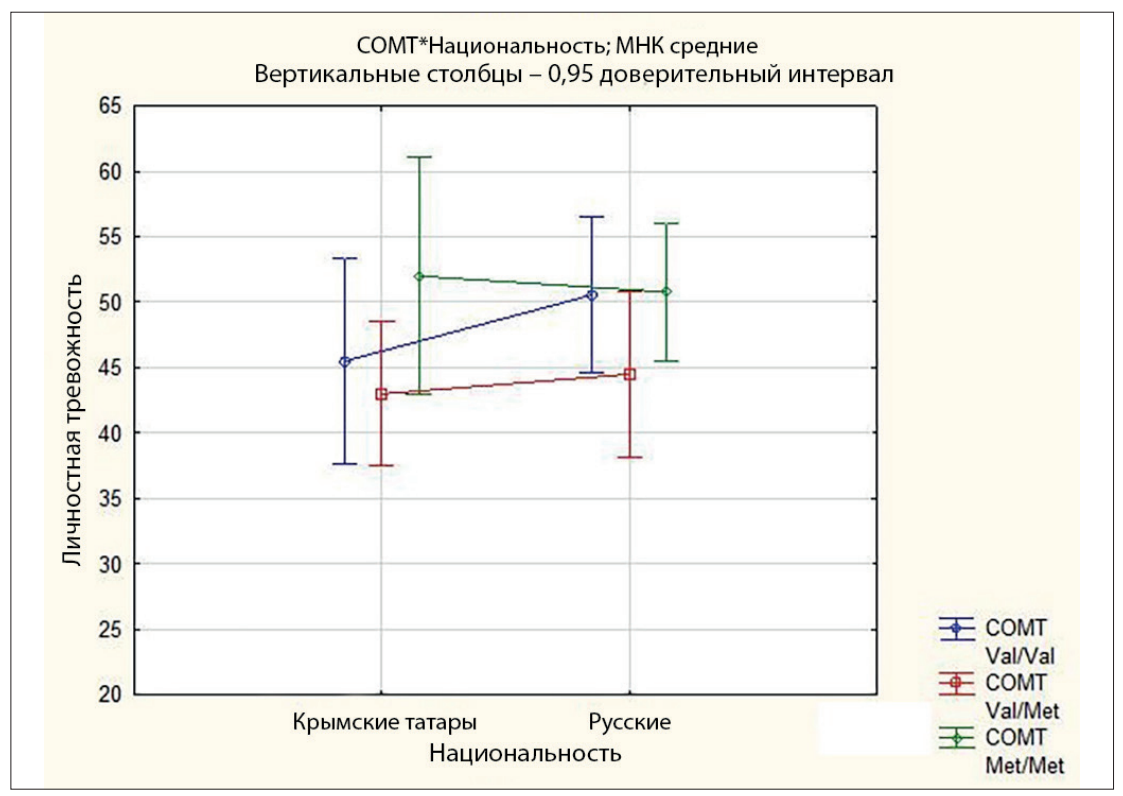

Рисунок 1. Результаты многодракторного Аисперсионного анализа ANOVA (независимые переменные - генотип по полиморфизму Val158Mеt гена COMT и этническая приналлежность, зависимая переменная - показатель ^ичностной тревожности по шкале тревоги Спи^бергера-Ханина)

Условные обозначения: синяя линия - генотиn Val/Val по гену COMT, красная линия - генотип $\mathrm{Val} / \mathrm{Met}$ по гену СОМT, зеленая линия-геноти Met/Met по гену COMT.

Figure 1. Results of univariate analysis of variance (ANOVA) (independent variables (a) COMT Val158Met gene polymorphism genotype and (b) ethnic group; dependent variable - index of trait anxiety (the Spielberger-Hanin anxiety test))

Legend: blue line indicates the Val/Val COMT genotype; red line indicates the Val/Met COMT genotype; green line indicates the Met/Met COMT genotype. 


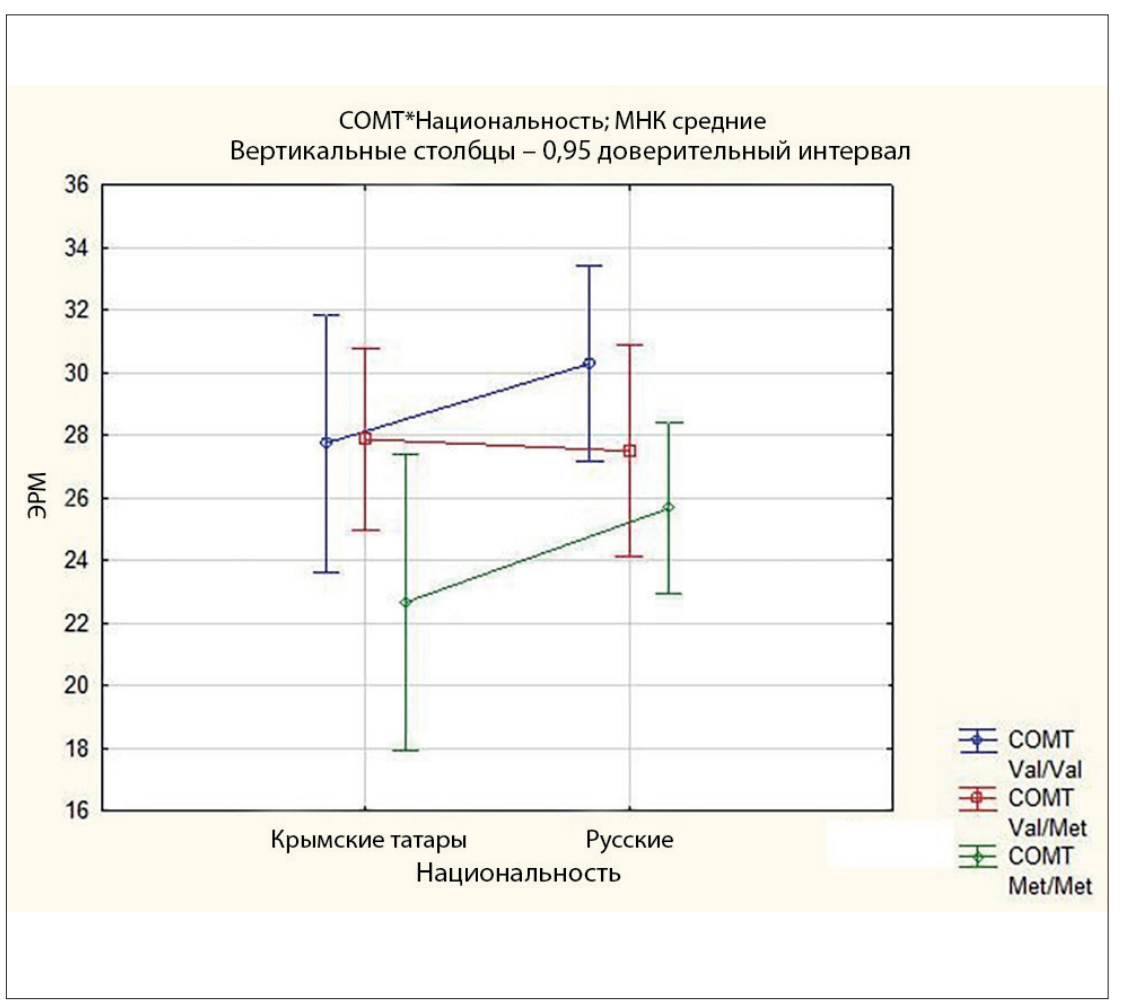

Рисунок 2. Результаты многофракторного Аисперсионного анализа ANOVA (независимые переменные - генотип по полиморфизму Val158Mеt гена СОМТ и этническая приналмежность, зависимая переменная-уровень моторной эргичности по ОФАСИ), у русских и татар, носителей различных генотипов гена СОМТ

Условные обозначения: синяя линия - генотиn $\mathrm{Val} / \mathrm{Val}$ по гену COMT, красная линия -генотип $\mathrm{Val} / \mathrm{Met}$ по гену СОМT, зеленая линия - генотиn Met/Met по гену СОМт.

Figure 2. Results of univariate analysis of variance (ANOVA) (independent variables (a) COMT Val158Met gene polymorphism genotype and (b) ethnic group; dependent variable - the level of motor ergicity among Russian and Tatar respondents bearing different COMT genotypes (the questionnaire of formal-dynamic characteristics of personality))

Legend: blue line indicates the Val/Val COMT genotype; red line indicates the Val/Met COMT genotype; green line indicates the Met/Met COMT genotype. 


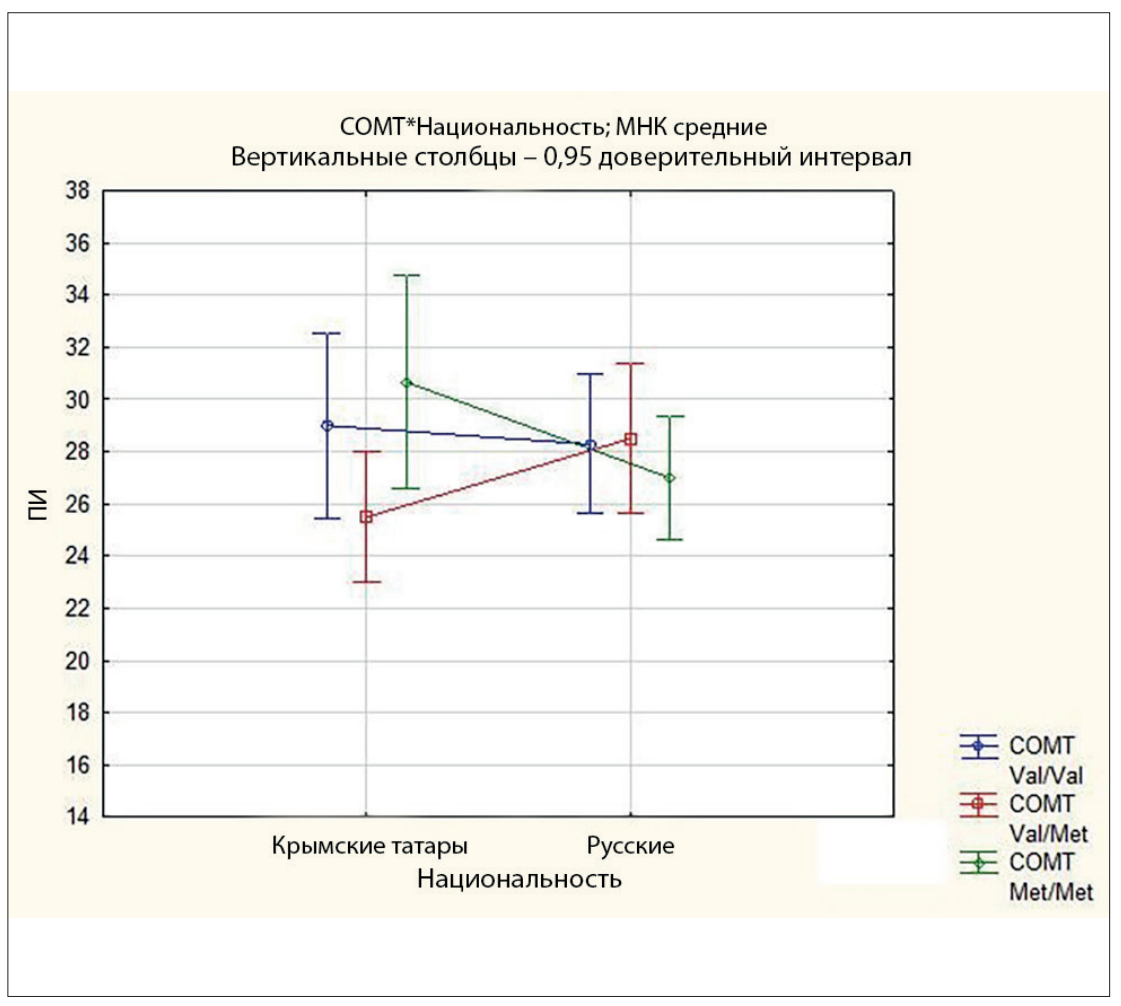

Рисунок 3. Результаты многофракторного Аисперсионного анализа ANOVA (независимые переменные - генотип по полиморфизму Val158Mеt гена СОМТ и этническая приналлежность, зависимая переменная - уровень интеллектуальной п^астичности по ОФАСИ), у русских и татар, носителей различных генотипов гена COMT

Условные обозначения: синяя линия - генотun Val/Val по гену COMT, красная линия -генотип $\mathrm{Val} / \mathrm{Met}$ по гену COMT, зеленая линия - генотиn Met/Met nо гену СОМT.

Figure 3. Results of univariate analysis of variance (ANOVA) (independent variables (a) COMT Val158Met gene polymorphism genotype and (b) ethnic group; dependent variable - the level of intellectual plasticity among Russian and Tatar respondents bearing different COMT genotypes (the questionnaire of formal-dynamic characteristics of personality))

Legend: blue line indicates the Val/Val COMT genotype; red line indicates the Val/Met COMT genotype; green line indicates the Met/Met COMT genotype. 


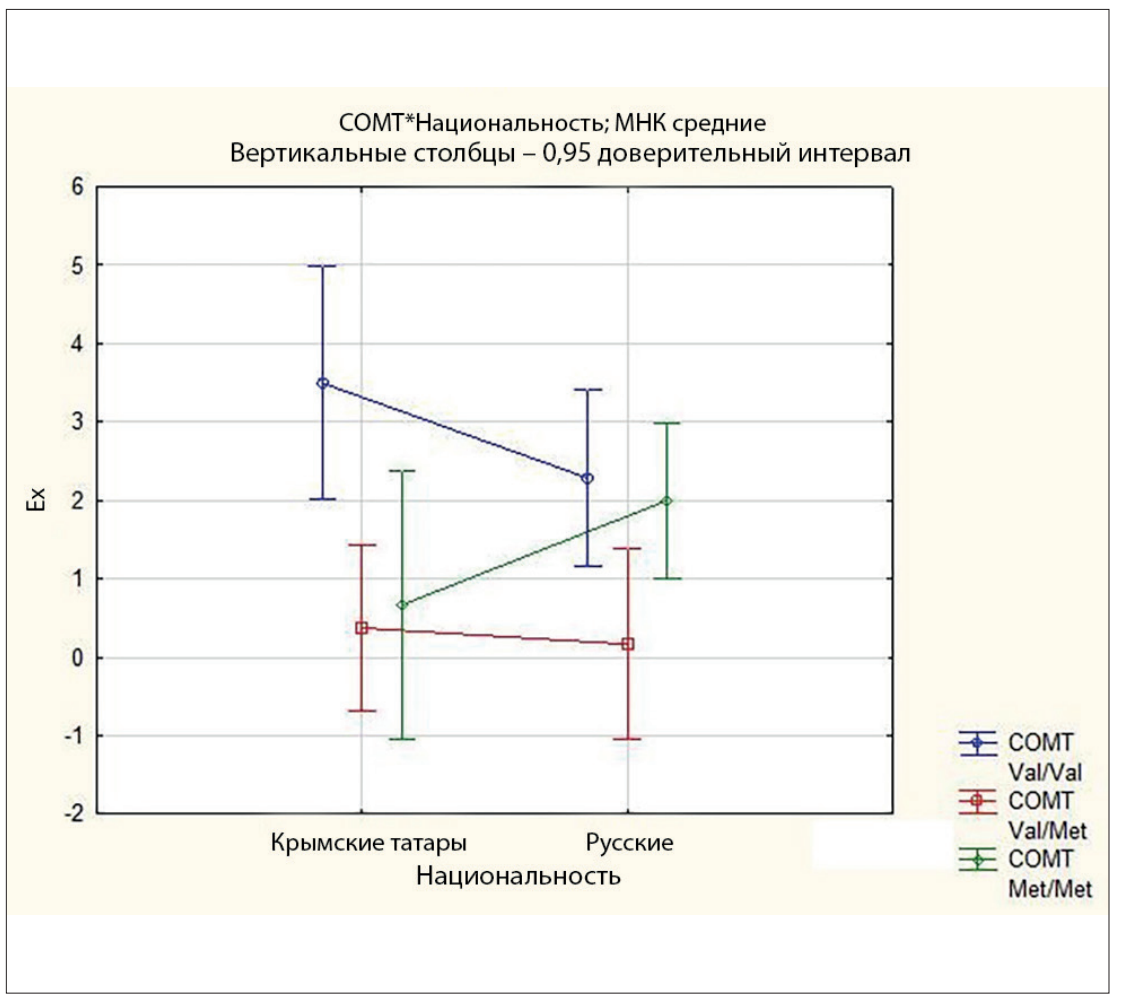

Рисунок 4. Результаты многофракторного Аисперсионного анализа ANOVA (независимые переменные - генотип по полиморфизму Val158Mеt гена СОМТ и этническая приналмежность, зависимая переменная - (Ех, эксгибиционизм) по «Handtest» Э. Вагнера), у русских и татар, носителей различных генотипов гена СОМТ

Условные обозначения: синяя линия - генотиn Val/Val по гену COMT, красная линия -генотип $\mathrm{Val} / \mathrm{Met}$ по гену СОМT, зеленая линия - генотиn Met/Met по гену СОМT.

Figure 4. Results of univariate analysis of variance (ANOVA) (independent variables (a) COMT Val158Met gene polymorphism genotype and (b) ethnic group; dependent variable-exhibitionism (EX) index among Russian and Tatar respondents bearing different COMT genotypes (the Wagner Hand Test))

Legend: blue line indicates the Val/Val COMT genotype; red line indicates the Val/Met COMT genotype; green line indicates the Met/Met COMT genotype. 


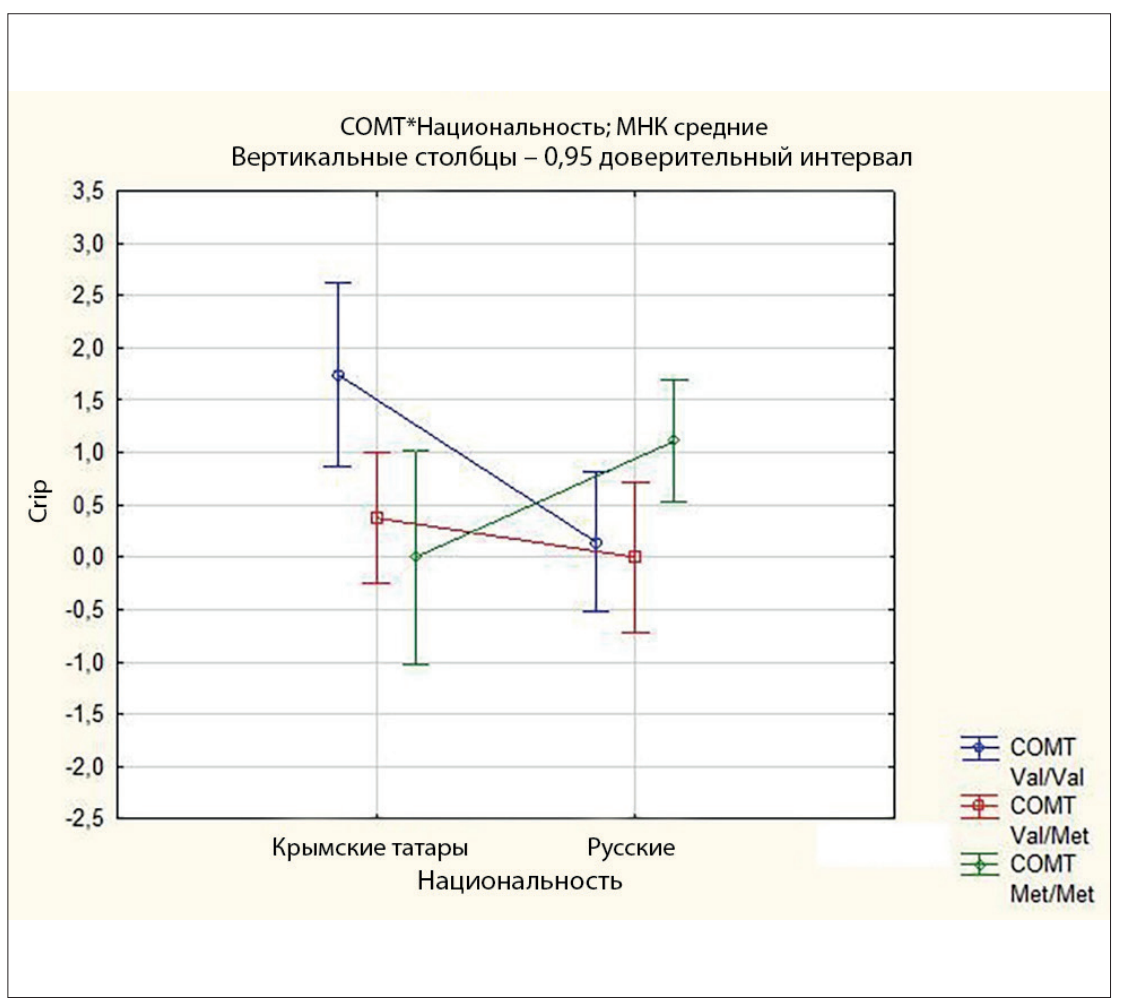

Рисунок 5. Результаты многодракторного Аисперсионного анализа ANOVA (независимые переменные -генотип по полимороризму Val158Mеt гена СОМТ и этническая приналлежность, зависимая переменная - показатель «калечность» (Crip) по «Handtest» Э. Вагнера), у русских и татар, носителей различных генотипов гена СОМТ

Условные обозначения: синяя линия-генотиn Val/Val по гену COMT, красная линия-генотun Val/ Met по гену СОМТ, зеленая линия-генотun Met/Met по гену СОМТ.

Figure 5. Results of univariate analysis of variance (ANOVA) (independent variables (a) COMT Val158Met gene polymorphism genotype and (b) ethnic group; dependent variable - crippled (CRIP) index among Russian and Tatar respondents bearing different COMT genotypes (the Wagner Hand Test))

Legend: blue line indicates the Val/Val COMT genotype; red line indicates the Val/Met COMT genotype; green line indicates the Met/Met COMT genotype. 
В группе татар к описанию руки (зависимая переменная - показатель «описание» (Des) по «Hand-test» Э. Вагнера) чаще всего прибегают носители генотипа Met/Met $(M=1, p=0,02)$; не используют данную категорию носители генотипа $\mathrm{Val} / \mathrm{Val}$ и $\mathrm{Val} / \mathrm{Met}(\mathrm{M}=0, \mathrm{p}=0,02)$ (рисунок 6).

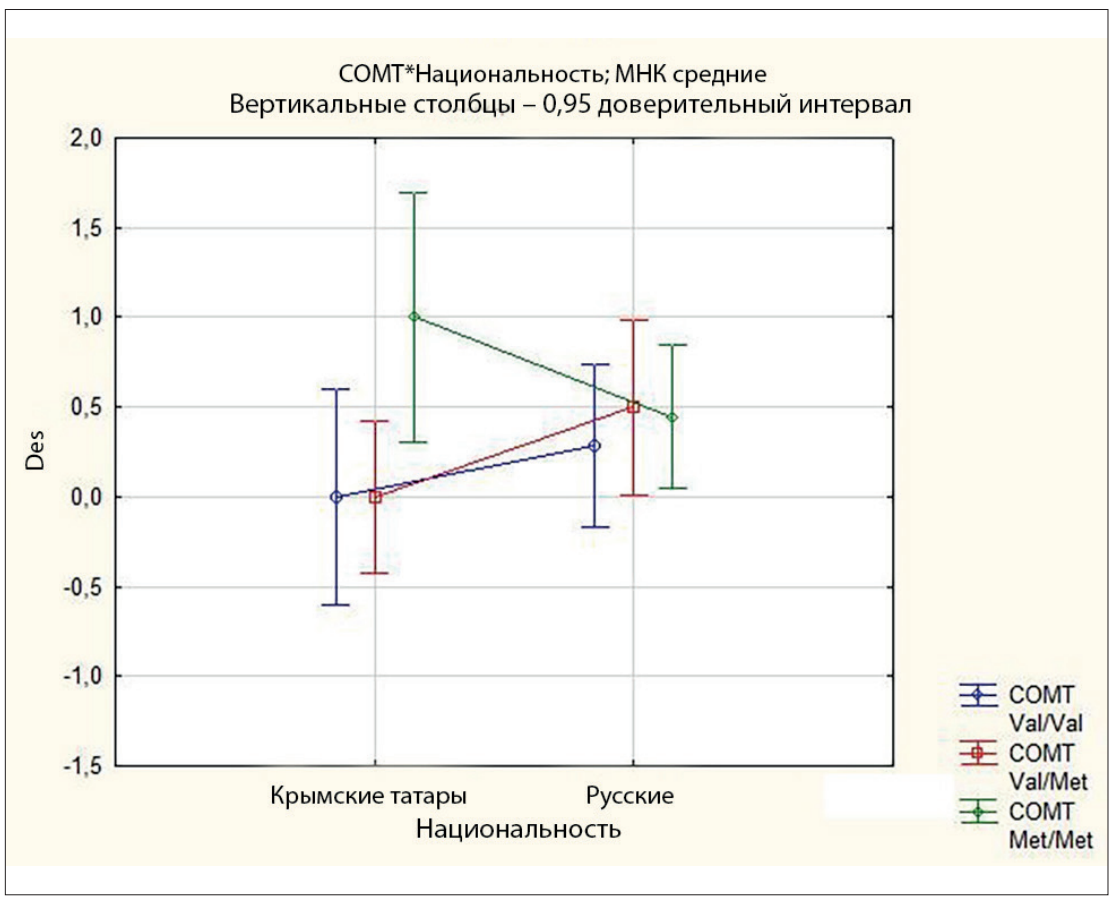

Рисунок 6. Результаты многофракторного Аисперсионного анализа ANOVA (независимые переменные - генотип по полиморфизму Val158Mеt гена СОМТ и этническая приналлежность, зависимая переменная - показатель «описание» (Des) по «Hand-test» Э. Вагнера), у русских и татар, носителей различных генотипов гена СОМт

Условные обозначения: синяя линия-генотиn $\mathrm{Val} / \mathrm{Val}$ nо гену COMT, красная линия-генотип $\mathrm{Val} / \mathrm{Met}$ по гену СОМT, зеленая линия - геноти Met/Met по гену СОМт.

Figure 6. Results of univariate analysis of variance (ANOVA) (independent variables (a) COMT Val158Met gene polymorphism genotype and (b) ethnic group; dependent variable-description (DES) index among Russian and Tatar respondents bearing different COMT genotypes (the Wagner Hand Test))

Legend: blue line indicates the Val/Val COMT genotype; red line indicates the Val/Met COMT genotype; green line indicates the Met/Met COMT genotype. 
Наиболее высокий уровень эмоционального напряжения (зависимая переменная - показатель «эмоциональное напряжение» (Ten) по «Hand-test» Э. Вагнера) продемонстрировали русские носители генотипа Val/Met (M = 2, p = 0,007), у представителей других групп данный фактор выражен достоверно в меньшей степени (рисунок 7).

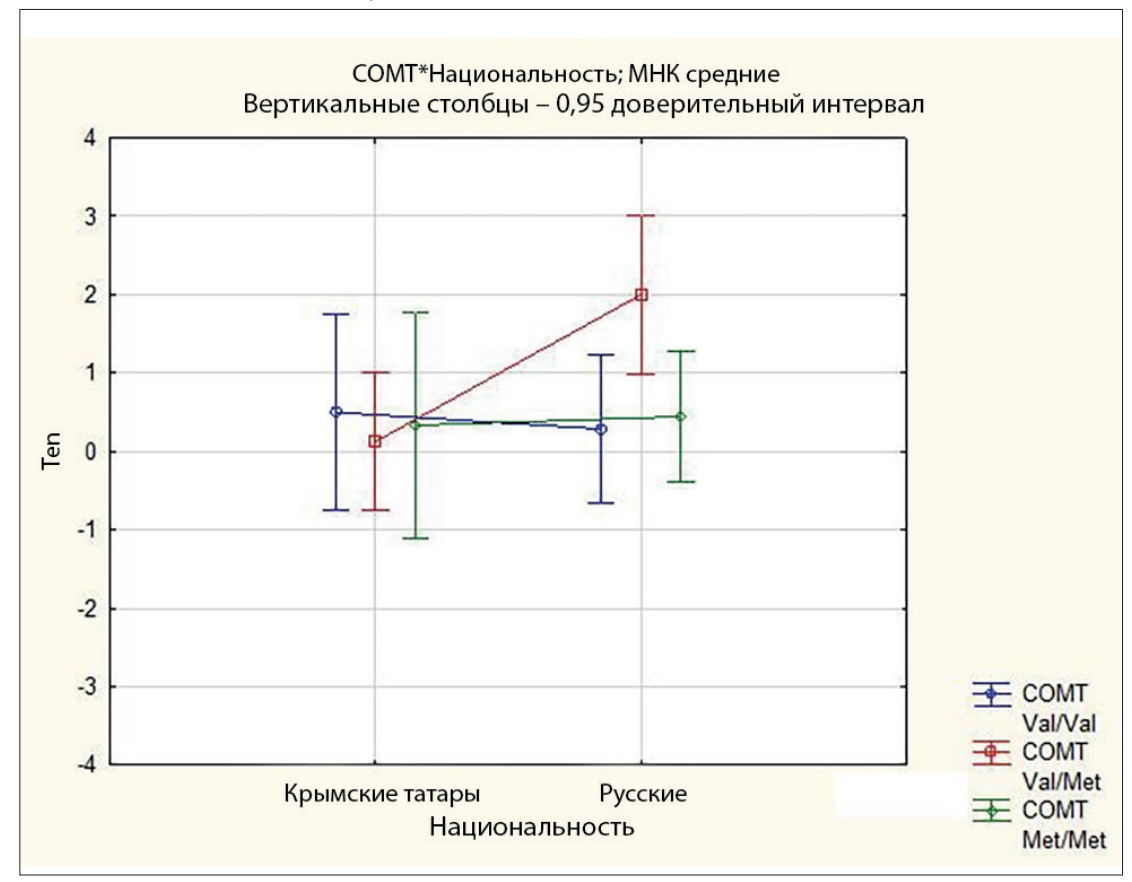

Рисунок 7. Результаты многофракторного Аисперсионного анализа ANOVA (независимые переменные - генотип по полимороизму Val158Mеt гена СОМТ и этническая приналлежность, зависимая переменная - показатель «напряжение» (Ten) по «Hand-test» Э. Вагнера), у русских и татар, носителей различных генотипов гена COMT

Условные обозначения: синяя линия -генотun Val/Val по гену COMT, красная линия-генотип $\mathrm{Val} / \mathrm{Met}$ по гену СОМт, зеленая линия - генотиn Met/Met по гену СОMT.

Figure 7. Results of univariate analysis of variance (ANOVA) (independent variables (a) COMT Val158Met gene polymorphism genotype and (b) ethnic group; dependent variable - tension (TEN) index among Russian and Tatar respondents bearing different COMT genotypes (the Wagner Hand Test))

Legend: blue line indicates the Val/Val COMT genotype; red line indicates the Val/Met COMT genotype; green line indicates the Met/Met COMT genotype. 
Интересен тот факт, что генотип Val/Met ассоциирован в группе русских с наиболее высоким уровнем выраженности дезадаптивных черт характеpa $(M=4,2, p=0,04)$, в то время как в группе татар связан с низким уровнем выраженности данной характеристики $(M=0,6, p=0,01)$ (зависимая переменная - показатель «психопатология» (РАTH) по «Hand-test» Э. Вагнера) (рисунок 8).

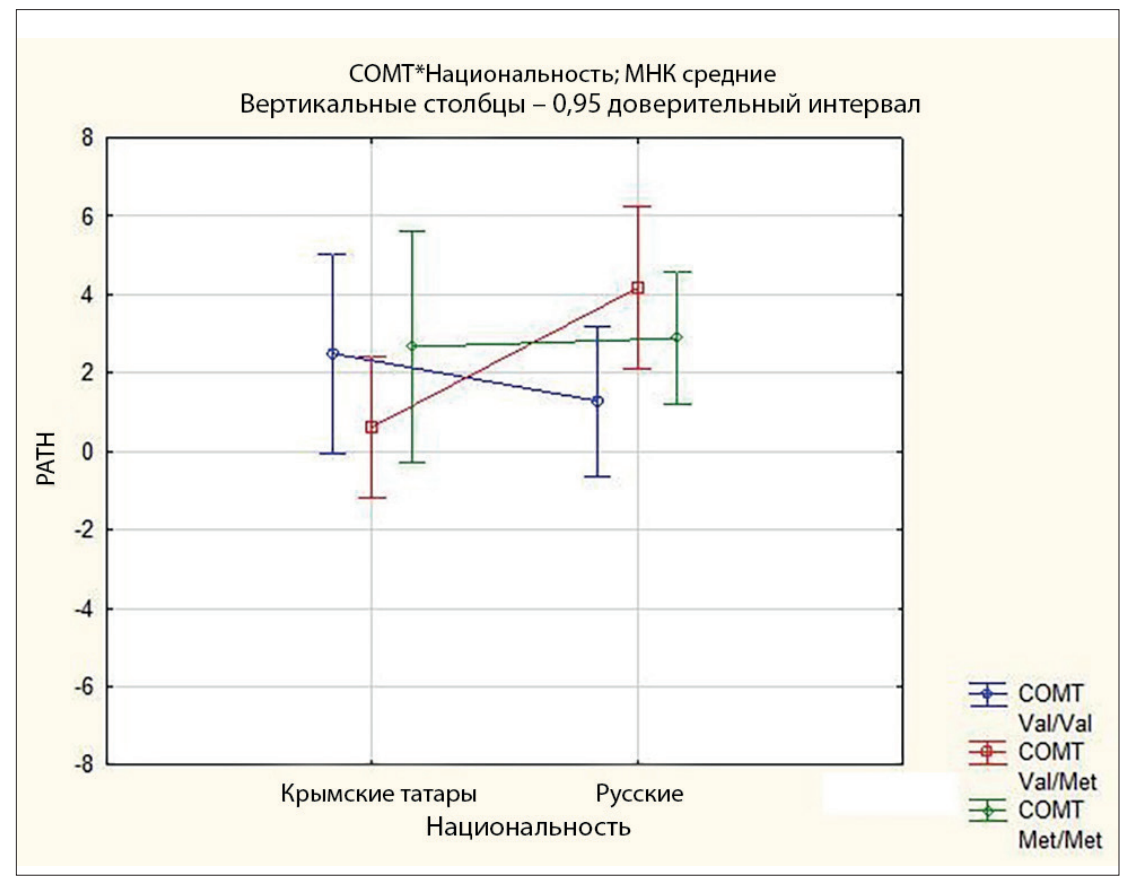

Рисунок 8. Результаты многофракторного Аисперсионного анализа ANOVA (независимые переменные - генотип по полиморфизму Val158Mеt гена СОМт и этническая приналлежность, зависимая переменная -показатель «психопатология» (РАТН) по «Hand-test») Э. Вагнера), у русских и татар, носителей различных генотипов гена COMT

Условные обозначения: синяя линия-генотиn Val/Val по гену COMT, красная линия-генотип $\mathrm{Val} / \mathrm{Met}$ по гену СОМТ, зеленая линия - генотиn Met/Met по гену СОMT.

Figure 8. Results of univariate analysis of variance (ANOVA) (independent variables (a) COMT Val158Met gene polymorphism genotype and (b) ethnic group; dependent variable - pathology (PATH) index among Russian and Tatar respondents bearing different COMT genotypes (the Wagner Hand Test))

Legend: blue line indicates the Val/Val COMT genotype; red line indicates the Val/Met COMT genotype; green line indicates the Met/Met COMT genotype. 
Сочетание ответов типа «Агрессивность» и «Директивность», отражающих готовность к открытому агрессивному поведению, нежелание приспосабливаться к социальному окружению (зависимая переменная - показатель «Суммарное значение агрессивности и директивности» (Ag + Dir) по «Hand-test» Э. Вагнера), достоверно более часто встречается в группах носителей генотипа Met/Met, независимо от национальности (Mp = 7,3, Mт = 7, $\mathrm{p}=0,04)$ (рисунок 9).

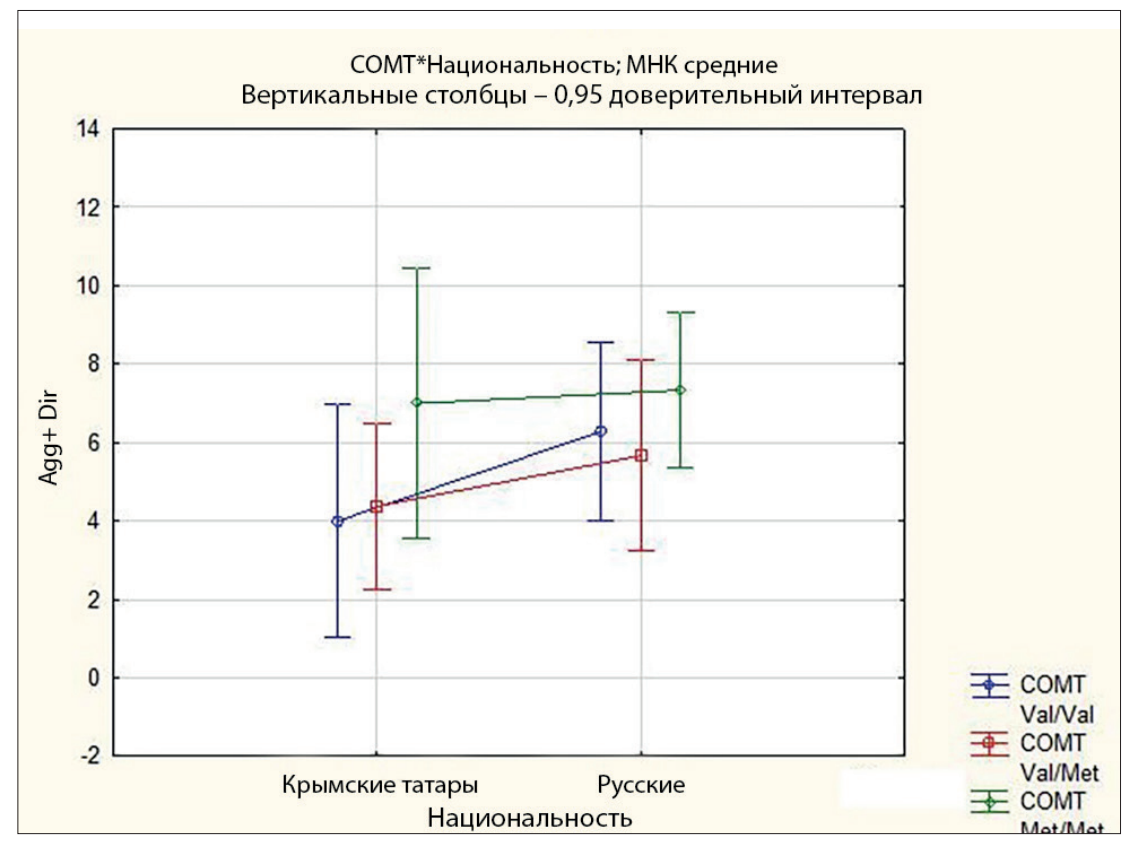

Рисунок 9. Результаты многофракторного Аисперсионного анализа ANOVA (независимые переменные - генотип по полиморфизму Val158Mеt гена СОМт и этническая приналлежность, зависимая переменная-показатель «Суммарное значение агрессивности и Аирективности» (Ag + Dir) по «Hand-test» Э. Вагнера), у русских и татар, носителей различных генотипов гена СОМТ.

Условные обозначения: синяя линия - генотun Val/Val по гену COMT, красная линия - генотип $\mathrm{Val} / \mathrm{Met}$ по гену СОМт, зеленая линия - генотиn Met/Met по гену СОMT.

Figure 9. Results of univariate analysis of variance (ANOVA) (independent variables (a) COMT Val158Met gene polymorphism genotype and (b) ethnic group; dependent variable - total score of aggression and direction (Ag + Dir) among Russian and Tatar respondents bearing different COMT genotypes (the Wagner Hand Test))

Legend: blue line indicates the Val/Val COMT genotype; red line indicates the Val/Met COMT genotype; green line indicates the Met/Met COMT genotype. 
пСихоФизиология

\section{Анализ половых различий}

Анализ данных, полученных по «Hand-test» показал, что наиболее выражен показатель «директивность» у русских женщин, носителей генотипа Met/ Met $(M=4,5, p=0,02)$. Комбинация показателей «агрессия» и «директивность» принимает наибольшие значения у русских женщин, носителей генотипа Met/ Met $(M=7,5, p=0,02)$, наименьшие - у татар, мужчин и женщин, носителей генотипа Val/Met (M =4,2, p = 0,02). Наиболее выражен показатель «коммуникация» у русских женщин (M=5,4, p=0,04), носителей генотипа Met/Met. Наиболее низкие показатели по шкале «демонстративность» имеют русские женщины, носители генотипа Val/Met $(M=0,2, p=0,007)$ и русские мужчины, носители генотипа Met/Met $(M=0, p=0,02)$, самые высокие - русские мужчины, носители генотипа Val/Val $(M=2, p=0,007)$ (рисунок 10).

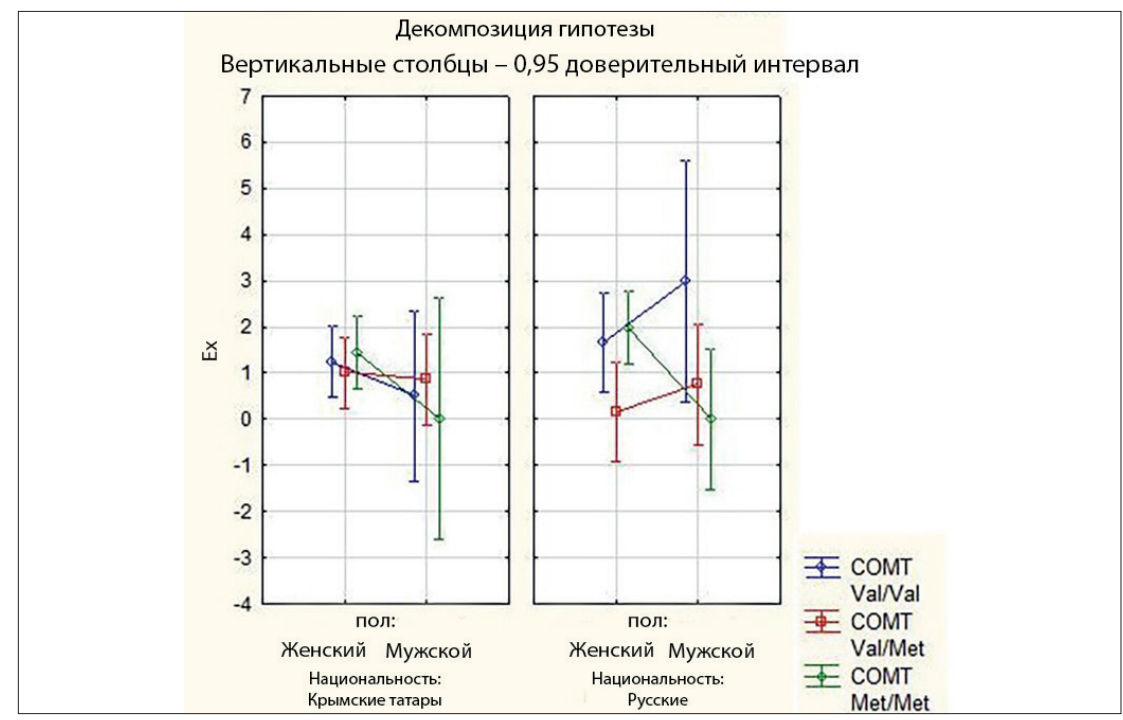

Рисунок 10. Частота встречаемости ответов категории «Аемонстративносты» при выполнении Hand-теста у мужчин и женщин - русских, татар, носителей различных генотипов гена СОМт

Условные обозначения: синяя линия - генотun Val/Val nо гену COMT, красная линия-генотип $\mathrm{Val} / \mathrm{Met}$ nо гену СОМT, зеленая линия-генотиn Met/Met nо гену COMT.

Figure 10. Frequency of exhibitionistic (EX) responses among Russian and Tatar respondents bearing different COMT genotypes (the Wagner Hand Test)

Legend: blue line indicates the Val/Val COMT genotype; red line indicates the Val/Met COMT genotype; green line indicates the Met/Met COMT genotype. 
Наиболее высокий показатель по шкале «калечность» имеют татарские женщины, носители генотипа Val/Val $(M=1,3, p=0,02)$, а также русские женщины, носители генотипа Met/Met (M=1,2, p=0,05), наиболее низкий-татарские женщины, носители генотипа Val/Met $(M=0,3, p=0,02)$, а также русские женщины, носители генотипа $\mathrm{Val} / \mathrm{Val}(\mathrm{M}=0,2, \mathrm{p}=0,02)$ (рисунок 11).

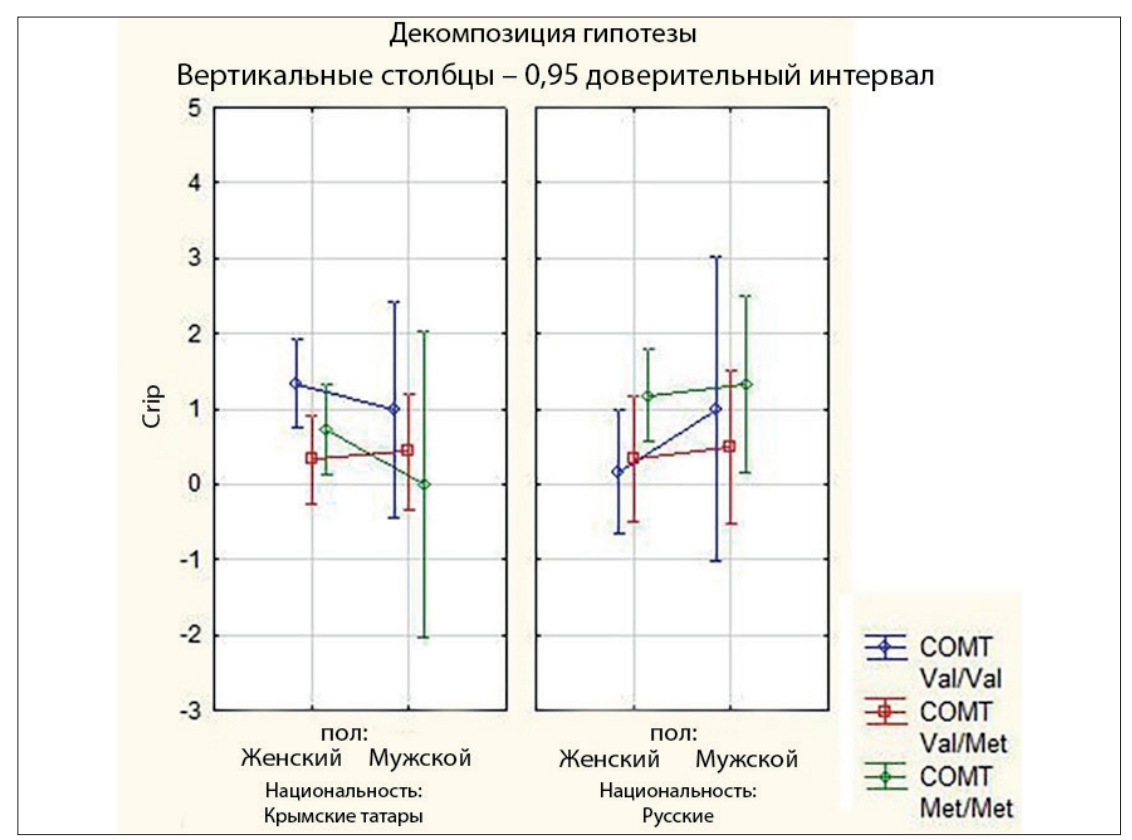

Рисунок 11. Частота встречаемости ответов категории «калечносты» при выполнении Hand-теста у мужчин и женщин - русских, татар, носителей различных генотипов гена COMT

Условные обозначения: синяя линия-генотun $\mathrm{Val} / \mathrm{Val}$ по гену COMT, красная линия -генотип $\mathrm{Val} / \mathrm{Met}$ по гену COMT, зеленая линия-геноти Met/Met по гену СОМт.

Figure 11. Frequency of crippled (CRIP) responses among Russian and Tatar respondents bearing different COMT genotypes (the Wagner Hand Test)

Legend: blue line indicates the Val/Val COMT genotype; red line indicates the Val/Met COMT genotype; green line indicates the Met/Met COMT genotype.

Наиболее выражен показатель «напряжение» у русских женщин, носительниц генотипа Val/Met $(M=2,2, p=0,004)$. Наиболее часто активные безличные ответы встречаются у русских мужчин, носителей генотипа Met/Met (M =9,7, $\mathrm{p}=0,02)$ (рисунок 12). 


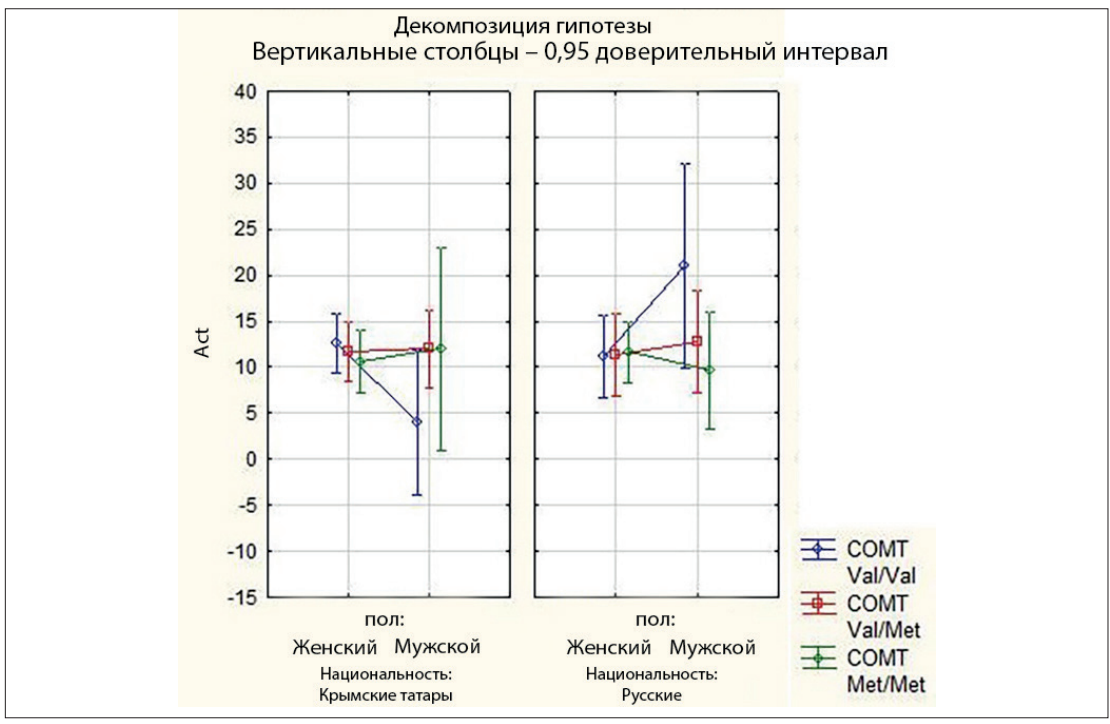

Рисунок 12. Частота встречаемости активных безличных ответов при выполнении Hand-теста у мужчин и женщин - русских, татар, носителей различных генотипов гена СОМТ

Условные обозначения: синяя линия - генотun Val/Val по гену COMT, красная линия -генотип $\mathrm{Val} / \mathrm{Met}$ по гену COMT, зеленая линия - генотun Met/Met по гену COMT.

Figure 12. Frequency of active impersonal responses among Russian and Tatar respondents bearing different COMT genotypes (the Wagner Hand Test)

Legend: blue line indicates the Val/Val COMT genotype; red line indicates the Val/Met COMT genotype; green line indicates the Met/Met COMT genotype.

Достоверно чаще других невероятные ответы (шкала «Bas») на вопрос о том, что делает рука, изображенная на картинке, давали русские обладательницы генотипа Val/Met $(\mathrm{M}=0,3, \mathrm{p}=0,003)$, в то время как у большинства опрошенных такие ответы не встречались. Наиболее часто отказывались давать ответы татары, мужчины, носители генотипа Val/Met $(M=0,3, p=0,003)$.

Комбинация факторов «эмоциональность + коммуникация + зависимость» получила наиболее высокие значения у русских женщин, носителей генотипа Met/Met $(M=7,1, p=0,006)$ и Val/Met $(M=6,3, p=0,006)$, носителей генотипа $\mathrm{Val} / \mathrm{Met}(\mathrm{M}=6,5, \mathrm{p}=0,02)$, в наименьшей степени-у русских мужчин, носителей генотипа $\mathrm{Val} / \mathrm{Met}(\mathrm{M}=3,5, \mathrm{p}=0,006)$.

Интересен тот факт, что у русских женщин генотип Val/Met ассоциирован с достоверно более высокими показателями переменных «степень личностной 


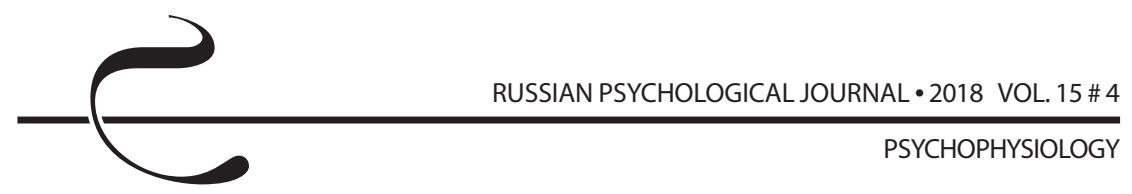

дезадаптации» и «психопатология» $(\mathrm{M}=3, \mathrm{p}=0,04 ; \mathrm{M}=4,7, \mathrm{p}=0,03)$, у татарских женщин - с достоверно более низкими $(\mathrm{M}=0,8, \mathrm{p}=0,04 ; \mathrm{M}=1,3, \mathrm{p}=0,02)$.

\section{Обсуждение результатов}

В нашей работе с применением многофакторного дисперсионного анализа были получены данные о том, что у носительниц генотиna Val/Nal no полиморфизму Val158Met гена СОМT, этнических татарок, достоверно выше показатели демонстративности и «калечности», полученные по методике «Hand-test», что проявляется в ассоциациях, отражающих стремление показать себя другим, участвовать в развлечениях; а также в ассоциациях, в которых рука воспринимается как поврежденная или деформированная. Для русской части выборки также характерны наиболее высокие показатели демонстративности у носителей генотипа Val/Val.

В работах других авторов было показано, что носители аллеля Val склонны к альтруизму, отличаются более высоко выраженным чувством сострадания и имеют преимущество при решении задач, содержащих эмоциональный компонент [33, 34]. Носители генотипа Val/Val имеют более адаптивный личностный профиль, что проявляется как более низкий уровень нейротизма и более высокий уровень ответственности и уступчивости [7]. С другой стороны, в клинических исследованиях было получено, что более выраженное снижение мотивации наблюдалось у носителей аллеля Met [35].

В нашей работе установлено, что носительницы генотиna Val/Met no полиморфизму Val158Mеt гена СОМТ, этнические русские, достоверно более высоко напряжены (тревожны), согласно данным, полученным по методике «Hand-test», и имеют черты психопатологии, что может быть связано с наличием одного аллеля Met в их генотипе. Напротив, у этнических татарок - носительниц генотипа Val/Met по полиморфизму Val158Met гена COMT достоверно менее выражены черты психопатологии, и снижена интеллектуальная пластичность.

Согласно описанию шкал «Hand-test», напряжение респонденток проявляется в ассоциациях на стимульный материал «Hand-test», в которых рука затрачивает определенную энергию, направленную на то, чтобы поддержать себя в трудной ситуации, что сопровождается переживаниями тревоги, напряжения и дискомфорта. Категория «напряжение» в «Hand-test» отражает такое свойство личности, как «тревожность» или «нейротизм» (имеется высокая прямая корреляция с соответствующими показателями опросников Айзенка, Кеттелла, MMPI). Тревожные люди характеризуются повышенным нервно-психическим напряжением в широком диапазоне ситуаций [32].

Оценка выраженности «психопатологии» в «Hand-test» проводится посредством дополнительного обсчета полученных данных, путем суммирования значения показателя второго порядка «степень личностной дезадаптации» (MAL) 
и удвоенного значения показателя второго порядка «тенденция к уходу от реальности» (WITH). Выраженная «психопатология» (по американским данным, РАТН > 4) может способствовать подавлению поведенческих тенденций или выведению их за грань контроля сознания [32].

В нашей работе установлено, что носительницы генотиna Met/Met no noлиморфизму Val158Met гена СОMT, этнические русские, имеют достоверно более высокий уровень личностной тревожности, диагностированной по методике Спилбергера - Ханина, по сравнению с носителями других генотипов, а также сниженный уровень моторной эргичности. Менее выраженная связь между генотипом Met/Met и описанными характеристиками характерна для татарской части выборки.

Полученные нами данные об ассоциации генотипа Val/Met по полиморфизму Val158Met гена СОМТ с повышенным уровнем напряжения (тревоги), диагностированным по методике «Hand-test», а также генотипа Met/Met c высоким уровнем личностной тревожности, диагностированной по методике Спилбергера - Ханина, подтверждаются данными других авторов, которыми было получено, что уровень тревоги растет с увеличением количества аллелей Met в генотипе носителей [36].

Как у русской, так и у татарской части выборки, согласно полученным нами данным, наличие генотипа Met/Met ассоциировано с достоверно более высоким суммарным показателем агрессивности и директивности, полученным на основе методики «Hand-test».

У татарской части выборки наличие генотипа Met/Met ассоциировано с большей склонностью давать простые описания руки, вместо ассоциаций о том, что мог бы делать человек, которому принадлежит рука. У русской части выборки наличие генотипа Met/Met ассоциировано с более высокой склонностью давать ответы, связанные с «калечностью» руки.

Обобщенные психологические особенности, связанные с этнической принадлежностью русских и татар, проживающих на территории Крыма, описаны и проанализированы посредством их отражения в мифах, сказках, легендах и пословицах [37]. Различия в генофондах тех или иных этнических групп определяются их длительной эволюцией, направленной на адаптацию к среде обитания. Средовые особенности, оказывая воздействие на носителей различных генотипов с разной этнической принадлежностью, могут вызывать различные фенотипические проявления [38].

Вопрос генотип-средового взаимодействия имеет особое значение для понимания специфики психологических особенностей носителей определенных генотипов, проживающих в различных регионах. Согласно результатам исследования ценностных ориентаций молодежи трех российских городов, проведенного И. В. Атамановой с соавт., экономический, культурный статус 
города (потенциал городской среды) привлекает молодежь с определенными личностными характеристиками [39]. К примеру, с одной стороны, Томск, как инновационный центр Сибири, привлекает молодежь с высоким интеллектуально-личностным потенциалом; с другой стороны, в городе созданы условия для реализации потенциала его жителей, что в результате проявляется в эффективном личностно-средовом взаимодействии. Описанные механизмы необходимо учитывать при изучении вклада различных генов в проявление психологических признаков. На сегодняшний день Крым - активно развивающийся регион Юга России, однако нестабильность социально-экономической обстановки может накладывать отпечаток на личностно-средовое взаимодействие, проявляясь в более высоких показателях агрессивности, тревожности и напряженности жителей. В то же время, необходимо помнить о том, что весьма сложно в естественных условиях изучить влияние генетических маркеров отдельно от средовых воздействий, в связи с чем социально-экономическая ситуация может рассматриваться как фактор, актуализирующий генетически обусловленные программы поведения.

Отметим также, что ранее были получены данные о межэтнических различиях в распознавании лицевой экспрессии представителями разных этносов [40]. В нашей работе впервые проведен анализ межэтнических различий распознания экспрессии «руки» у представителей этносов, проживающих на Юге России, в республике Крым и имеющих разные генотипы по полиморфизму Val158Met гена COMT.

\section{Заключение}

Исследование позволило сделать следующие выводы:

1. Проведенное исследование показало наличие достоверно более высокого суммарного показателя агрессивности и директивности (по методике «Handtest») у представителей русской и татарской этнических групп с генотипами Met/Met по полиморфизму Val158Met гена СОМТ, наряду с более высоким уровнем личностной тревожности (по методике Спилбергера - Ханина) и низкой моторной эргичностью (по опроснику В. М. Русалова).

2. Наличие генотипа Val/Val по полиморфизму Val158Met гена COMT у девушек- этнических татарок сопряжено с наличием таких психологических особенностей, как склонность к самовыражению и самопрезентации, что выявляется шкалой «демонстративность» проективной методики «Hand-test» Э. Вагнера.

3. Наличие генотипа Val/Met по полиморфизму Val158Met гена COMT у девушек - этнических русских сопряжено с проявлением у них личностных черт напряжения (тревоги) и проявлений «психопатологии», проявляющейся как суммарный показатель «степени личностной дезадаптации» и «тенденции к уходу от реальности» по методике «Hand-test». 
4. Полученные в нашей работе результаты свидетельствуют в пользу возможности создания корригирующих условий среды для носителей генотипов, ассоциированных в разных этнических группах с дезадаптивными личностными характеристиками.

\section{Благодарности}

Работа выполнена при поддержке Российского научного фонда (проект № 213.0103/2016-4, соглашение № 16-18-10222).

\section{Acknowledgments}

Supported by the Russian Science Foundation, project no. 213.01-03/2016-4, agreement no. 16-18-10222.

\section{Литература}

1. Лучинкина А. И. Особенности этнической социализации в поликультурном обществе // Ученые записки Крымского инженерно-педагогического университета. Серия: Педагогика. Психология. 2016. № 1 (3). С. 121-128.

2. Ковас Ю. В., Малых С. Б. Заключение: перспективы поведенческой геномики в образовании // Геномика поведения: детское развитие и образование / под ред. С. Б. Малых, Ю. В. Ковас, Д. А. Гайсиной. Томск: Изд-во Национального исследовательского Томского государственного университета, 2016. С. 382-390.

3. Алфимова М. В., Трубников В.И. Психогенетика агрессивности // Вопросы психологии. 2000. № 6. С. 112-122.

4. Мустафина Т. Б., Леопольд А. В., Павлов К. А., Кекелидзе З. И., Макушкин Е. В., Фастовиов Г. А., Чехонин В. П. Генетические аспекты агрессивного поведения у больных шизофренией (аналитический обзор) // Российский психиатрический журнал. 2014. № 3. С. 67-78.

5. Schindler K. M., Richter M. A., Kennedy J. L., Pato M. T., Pato C. N. Association between homozygosity at the COMT gene locus and obsessive compulsive disorder // American Journal of Medical Genetics. 2000. № 96. P. 721-724.

6. Montag C., Buckholtz J. W., Hartmann P., Merz M., Burk C., Hennig J., Reuter M. COMT Genetic Variation Affects Fear Processing: Psychophysiological Evidence // Behavioral Neuroscience. 2008. Vol. 122, № 4. P. 901-909. DOI: 10.1037/0735-7044.122.4.901

7. Kotyuk E., Duchek J., Head D., Szekely A., Goate A. M., Balota D. A. A genetic variant (COMT) coding dopaminergic activity predicts personality traits in healthy elderly // Personality and Individual Differences. 2015. Vol. 82. P. 61-66. DOI: 10.1016/j.paid.2015.03.012 
8. Конарева И. Н. Исследование черт личности в психогенетике: факты и гипотезы // Ученые записки Крымского федерального университета имени В. И. Вернадского. Биология. Химия. 2017. Т. 3 (69), № 4. С. 127-137.

9. Tuvblad C., Narusyte J., Comasco E., Andershed H., Andershed A.-K., Colins O. F., Fanti K. A., Nilsson K. W. Physical and verbal aggressive behavior and COMT genotype: Sensitivity to the environment // American Journal of Medical Genetics Part B: Neuropsychiatric Genetics. 2016. Vol. 171, Issue 5. P. 708-718. DOI: 10.1002 /ajmg.b.32430

10. Dumontheil I., Roggeman C., Ziermans T., Peyrard-Janvid M., Matsson H., Kere J., Klingberg T. Influence of the COMT Genotype on Working Memory and Brain Activity Changes During Development // Biological Psychiatry. 2011. Vol. 70, Issue 3. P. 222-229. DOI: 10.1016/j.biopsych.2011.02.027

11. Ковш Е. М., Воробьева Е. В., Ермаков П. Н., Абакумова И. В. Индивидуально-психологические особенности мужчин иженщин, носителей различных генотипов по полиморфизму Val158Met (g472a) гена СОМТ // Материалы съезда Российского психологического общества. Казань: Изд-во Казанского (Приволжского) федерального университета, 2017. С. 341-343.

12. Крючкова А. С., Ермаков П.Н., Абакумова И. В. Психогенетические особенности агрессивных и враждебных стратегий поведения у подростков и молодых людей разной этнической принадлежности // Известия Южного федерального университета. Педагогические науки. 2016. № 1. C. 77-83.

13. Марютина Т. М. Эндофенотипы в психиатрической генетике: опыт десяти лет изучения (Обзор литературы) // Современная зарубежная психология. 2013. Т. 2, № 4. С. 45-58.

14. Muscatello M. R. A., Scimeca G., Bruno A., Pandolfo G., Micò U., Bellinghieri P. M., Zoccali R. Anger and Adolescence: A Psychometric Investigation on a Sample of Italian High School Students (Book Chapter) // Psychology of Anger: Symptoms, Causes and Coping / J. P. Welty (Ed.). New York, Nova Science Publishers, 2011. P. 83-112.

15. Зверева М. В., Ениколопов С. Н., Олейчик И. В. Прокрастинация и агрессия при психической патологии у лиц молодого возраста // Психологическая наука и образование. 2015. Т. 20, № 2. С. 70-77.

16. Ковш Е. М., Воробьева Е. В., Ермаков П. Н. Обзор современных исследований психогенетических факторов агрессивного поведения // Российский психологический журнал. 2014. Т. 11, № 4. С. 91-103. DOI: 10.21702/rpj.2014.4.7

17. Воробьева Е. В., Ермаков П. Н., Абакумова И. В., Ковш Е. М., Крючкова А. С. Психогенетика агрессивного и враждебного поведения: учебное пособие. Ростов-на-Дону: Изд-во ЮФУ, 2016. 102 с. 
18. Воронин А. Н., Лучинина Е. В. Влияние социальной микросреды на проявления агрессивности // Прикладная юридическая психология. 2014. № 2. C. 97-113.

19. Ковш Е. М., Ермаков П. Н., Воробьева Е. В. Ассоциация полиморфного маркера Val158Met гена СОМТ с уровнем агрессивности и стратегиями поведения в конфликте у девушек 18-24 лет // Северо-Кавказский психологический вестник. 2015. № 13/3. С. 15-21.

20. Воробьева Е. В., Перков М. А., Щетинина Д. П. Исследование взаимосвязи принятия агрессии и эмоционального интеллекта // Российский психологический журнал. 2017. T. 14, № 2. C. 28-50. DOI: 10.21702/rpj.2017.2.2

21. Михайленко О. И. Полиэтническая компетентность в системе компетентностного подхода в образовании // Научная мысль Кавказа. 2013. № 4 (76). С. 78-82.

22. Павлова О. С., Семёнова Ф. О. Ценностные ориентации мусульманской молодёжи Северо-Западного Кавказа // Minbar. Islamic Studies. 2018. T. 11, № 2. C. 361-374. DOI: 10.31162/2618-9569-2018-11-2-361-374

23. Берсирова А. К., Шхахутова 3. 3. Межэтнические взаимоотношения в современном российском обществе // Этносоциальные процессы: в поисках инновационной методологии: материалы международной научно-практической конференции. Майкоп: Электронные издательские технологии, 2016. С. 23-26.

24. Хакунова Ф. П., Мовсесян Э. М. Культурно-образовательное пространство как фактор формирования толерантности школьников // Вестник Майкопского государственного технологического университета. 2014. № 4. С. 96-102.

25. Ениколопов С. Н. Методы исследования агрессии в клинической психологии // Диагностика в медицинской психологии: традиции и перспективы / под общ. ред. Н. В. Зверевой, И. Ф. Рощиной. М., 2011. С. 82-100.

26. Ахметзянова А. И. Применение теста руки «Hand - test» (Вагнер Э.) в исследовании ассоциативно-диссоциативных механизмов деструктивного поведения подростков // Коллекция гуманитарных исследований. 2016. № 1 (1). С. 62-68.

27. Макушкина О. А., Буравцов К. А., Дурнева М. Ю. Клинико-социальные особенности и агрессивное поведение пациентов при длительных сроках исполнения принудительных мер медицинского характера // Обозрение психиатрии и медицинской психологии имени В. М. Бехтерева. 2017. № 1. С. 45-52.

28. Шамова Т. М., Карпович-Мисник А. В. Характеристика личности больных рассеянным склерозом по данным проективного метода «Hand-test» // Журнал Гродненского государственного медицинского университета. 2007. № 4 (20). С. 80-82. 
29. Беломестнова Н. В. Опыт применения методики the hand test в практике судебно-психологической экспертизы в уголовном процессе // Теория и практика судебной экспертизы: международный опыт, проблемы, перспективы: сборник научных трудов I Международного форума. М.: Изд-во Московского университета МВД России имени В. Я. Кикотя, 2017. C. 415-420.

30. Стресс и тревога в спорте: Международный сборник научных статей / сост. Ю. Л. Ханин. М.: Физкультура и спорт, 1983. 288 с.

31. Русалов В. М. Темперамент в структуре индивидуальности человека: дифференциально-психофизиологические и психологические исследования. М.: Изд-во ИП РАН, 2012.528 с.

32. Курбатова Т. Н., Муляр О. Н. Проективная методика исследования личности «Hand-test». Методическое руководство. СПб.: ГМНППП «ИМАТОН», 2001.64 c.

33. Witte A. V., Flöel A. Effects of COMT polymorphisms on brain function and behavior in health and disease // Brain Research Bulletin. 2012. Vol. 88, Issue 5. P. 418-428. DOI: 10.1016/j.brainresbull.2011.11.012

34. Кухтинская Л. В., Зураев А. В., Будевич В. А., Моссэ И. Б. Современные представления о генетических детерминантах психоэмоциональной устойчивости человека // Молекулярная и прикладная генетика. 2016. T. 20. C. 96-109.

35. Schneider M., Van der Linden M., Glaser B., Rizzi E., Dahoun S. P., Hinard C., Bartoloni L., Antonarakis S. E., Debbané M., Eliez S. Preliminary structure and predictive value of attenuated negative symptoms in $22 \mathrm{q} 11.2$ deletion syndrome // Psychiatry Research. 2012. Vol. 196, Issues 2-3. P. 277-284. DOI: $10.1016 /$ j.psychres.2011.08.017

36. Спасова А. П., Курбатова И. В., Барышева О. Ю., Тихова Г. П. Влияние полиморфизма гена катехол-О-метилтрансферазы на эффективность обезболивания у онкологических больных // Российский журнал боли. 2016. № 3-4 (51). С. 32-42.

37. Лучинкина А. И. Этнос, этничность, этноидентичность, этническая индивидуация и этническая социализация в поликультурном обществе // Межкультурные взаимодействия в поликультурном обществе. Симферополь: ИП Хотеева Л.В., 2016. С. 43-63.

38. Кучер А. Н. Ген-средовые взаимодействия как основа формирования здоровья // Экологическая генетика. 2017. Т. 15, № 4. С. 19-32. DOI: 10.17816/ecogen15419-32

39. Атаманова И. В., Козлова Н. В., Богомаз С. А., Залевский В. Г., НеяскинаЮ. Ю. Специфика личностно-средового взаимодействия на примере студенческой молодежи трех российских городов // Вестник Томского 
государственного университета. Философия. Социология. Политология. 2018. № 41. С. 90-105.

40. Карабущенко Н. Б., Хворова Е. М. Межэтнические особенности распознавания лицевой экспрессии // Вестник Мининского университета. 2017. № 3 (20). DOI: 10.26795/2307-1281-2017-3-14

\section{References}

1. Luchinkina A. I. Features of ethnic socialization in a multicultural society. Uchenye zapiski Krymskogo inzhenerno-pedagogicheskogo universiteta. Seriya: Pedagogika. Psikhologiya - Scientific Notes of the Crimean Engineering Pedagogical University. Series: Pedagogy, Psychology, 2016, no. 1 (3), pp. 121-128 (in Russian).

2. Kovas Yu. V., Malykh S. B. Conclusion: Prospects for behavioral genomics in education. In: B. Malykh, Yu. V. Kovas, D. A. Gaisina (eds.) Genomika povedeniya: detskoe razvitie i obrazovanie [Genomics of behavior: Child development and education]. Tomsk, National Research Tomsk State University Publ., 2016, pp. 382-390.

3. Alfimova M. V., Trubnikov V. I. Psychogenetics of aggression. Voprosy Psikhologii, 2000, no. 6, pp. 112-122 (in Russian).

4. Mustafina T. B., Leopol'd A. V., Pavlov K. A., Kekelidze Z. I., Makushkin E. V., Fastovtsov G. A., Chekhonin V. P. Genetic aspects of aggressive behavior in patients with schizophrenia: analytical review. Rossiiskii psikhiatricheskii zhurnal - Russian Journal of Psychiatry, 2014, no. 3, pp. 67-78 (in Russian).

5. Schindler K. M., Richter M. A., Kennedy J. L., Pato M. T., Pato C. N. Association between homozygosity at the COMT gene locus and obsessive compulsive disorder. American Journal of Medical Genetics, 2000, no. 96, pp. 721-724.

6. Montag C., Buckholtz J. W., Hartmann P., Merz M., Burk C., Hennig J., Reuter M. COMT genetic variation affects fear processing: Psychophysiological evidence. Behavioral Neuroscience, 2008, V. 122, no. 4, pp. 901-909. DOI: 10.1037/0735-7044.122.4.901

7. Kotyuk E., Duchek J., Head D., Szekely A., Goate A. M., Balota D. A. A genetic variant (COMT) coding dopaminergic activity predicts personality traits in healthy elderly. Personality and Individual Differences, 2015, V. 82, pp. 61-66. DOI: 10.1016/j.paid.2015.03.012

8. Konareva I. N. Studying personality traits in psychogenetics: Facts and hypotheses. Uchenye zapiski Krymskogo federal'nogo universiteta imeni V. I. Vernadskogo. Seriya "Biologiya, khimiya" - Scientific Notes of V. I. Vernadsky Crimean Federal University. Biology. Chemistry, 2017, V. 3 (69), no. 4, pp. 127-137 (in Russian). 
9. Tuvblad C., Narusyte J., Comasco E., Andershed H., Andershed A.-K., Colins O. F., Fanti K. A., Nilsson K. W. Physical and verbal aggressive behavior and COMT genotype: Sensitivity to the environment. American Journal of Medical Genetics Part B: Neuropsychiatric Genetics, 2016, V. 171, Issue 5, pp. 708-718. DOI: 10.1002/ajmg.b.32430

10. Dumontheil I., Roggeman C., Ziermans T., Peyrard-Janvid M., Matsson H., Kere J., Klingberg T. Influence of the COMT genotype on working memory and brain activity changes during development. Biological Psychiatry, 2011, V. 70, Issue 3, pp. 222-229. DOI: 10.1016/j.biopsych.2011.02.027

11. Kovsh E. M., Vorobyeva E. V., Ermakov P. N., Abakumova I. V. Individual'nopsikhologicheskie osobennosti muzhchin i zhenshchin, nositelei razlichnykh genotipov po polimorfizmu Val158Met (g472a) gena COMT [Individual psychological characteristics in men and women bearing different Val158Met (g472a) gene polymorphism genotypes]. Materialy s"ezda Rossiiskogo psikhologicheskogo obshchestva [Proc. the Congress of the Russian Psychological Society]. Kazan, Kazan (Volga region) Federal University Publ., 2017, pp. 341-343.

12. Kryuchkova A. S., Ermakov P. N., Abakumova I. V. Psychogenetic characteristics of aggressive and hostile strategies of behavior in adolescents and young adults from various ethnic groups. Izvestiya Yuzhnogo federal'nogo universiteta. Pedagogicheskie nauki - Proceedings of the Southern Federal University. Pedagogical Science, 2016, no. 1, pp. 77-83 (in Russian).

13. Maryutina T. M. Endophenotypes in psychiatric genetics: Experience of ten years long study: A literature overview. Sovremennaya zarubezhnaya psikhologiya - Journal of Modern Foreign Psychology, 2013, V. 2, no. 4, pp. 45-58 (in Russian).

14. Muscatello M. R. A., Scimeca G., Bruno A., Pandolfo G., Micò U., Bellinghieri P. M., Zoccali R. Anger and adolescence: A psychometric investigation on a sample of Italian high school students (book chapter). In: J. P. Welty (ed.) Psychology of anger:Symptoms, causes, and coping. New York, Nova Science Publishers, 2011, pp. 83-112.

15. Zvereva M. V., Enikolopov S. N., Oleichik I. V. Procrastination and aggression for mental disorders in young people. Psikhologicheskaya nauka iobrazovanie Psychological Science and Education, 2015, V. 20, no. 2, pp. 70-77 (in Russian).

16. Kovsh E. M., Vorobyeva E. V., Ermakov P. N. Review of modern researches of psychogenetic factors of aggressive behavior. Rossiiskii psikhologicheskii zhurnal - Russian Psychological Journal, 2014, V. 11, no. 4, pp. 91-103 (in Russian). DOI: 10.21702/rpj.2014.4.7

17. Vorobyeva E. V., Ermakov P. N., Abakumova I. V., Kovsh E. M., Kryuchkova A. S. Psikhogenetika agressivnogo i vrazhdebnogo povedeniya [Psychogenetics of aggressive and hostile behavior]. Rostov-on-Don, SFU Publ., 2016. 102 p. 
18. Voronin A. N., Luchinina E. V. Impact of social micro-environment on manifestations of aggression. Prikladnaya yuridicheskaya psikhologiya-Applied Legal Psychology, 2014, no. 2, pp. 97-113 (in Russian).

19. Kovsh E. M., Ermakov P. N., Vorobyeva E. V. Association of the COMT Val158Met polymorphic marker with the level of aggressiveness and strategies of behavior in conflict among girls aged 18-24 years. Severo-Kavkazskii psikhologicheskii vestnik - North-Caucasian Psychological Bulletin, 2015, no. 13/3, pp. 15-21 (in Russian).

20. Vorobyeva E. V., Perkov M. A., Shchetinina D. P. Studying the association between acceptance of aggression and emotional intelligence. Rossiiskii psikhologicheskii zhurnal - Russian Psychological Journal, 2017, V. 14, no. 2, pp. 28-50 (in Russian). DOI: 10.21702/rpj.2017.2.2

21. Mikhailenko O. I. Polyethnic competence in the system of competence approach in education. Nauchnaya mysl' Kavkaza - Scientific Thought of the Caucasus, 2013, no. 4 (76), pp. 78-82 (in Russian).

22. Pavlova O. S., Semenova F. O. Value orientations of Muslim youth in the NorthWestern Caucasus. Minbar. Islamic Studies, 2018, V. 11, no. 2, pp. 361-374 (in Russian). DOI: 10.31162/2618-9569-2018-11-2-361-374

23. Bersirova A. K., Shkhakhutova Z. Z. Mezhetnicheskie vzaimootnosheniya v sovremennom rossiiskom obshchestve [Inter-ethnic relations in the modern Russian society]. Materialy mezhdunarodnoi nauchno-prakticheskoi konferentsii Etnosotsial'nye protsessy: v poiskakh innovatsionnoi metodologii [Proc. the International Theoretical and Practical Conference "Ethno-social processes: Searching innovative methodology"]. Maikop, Elektronnye izdatel'skie tekhnologii Publ., 2016, pp. 23-26.

24. Khakunova F. P., Movsesyan E. M. Cultural and educational space as a factor for schoolchildren's tolerance. Vestnik Maikopskogo gosudarstvennogo tekhnologicheskogo universiteta - Bulletin of Maikop State Technological University, 2014, no. 4, pp. 96-102 (in Russian).

25. Enikolopov S. N. Methods of studying aggression in clinical psychology. In: N. V. Zvereva, I. F. Roshchina (eds.) Diagnostika v meditsinskol psikhologii: traditsii i perspektivy [Diagnosis in medical psychology: traditions and prospect]. Moscow, 2011, pp. 82-100 (in Russian).

26. Akhmetzyanova A. I. Using the Wagner Hand Test in the study of associative and dissociative mechanisms of destructive behavior in adolescents. Kollektsiya gumanitarnykh issledovanii-Collection of Humanitarian Studies, 2016, no. 1 (1), pp. 62-68 (in Russian).

27. Makushkina O. A., Buravtsov K. A., Durneva M. Yu. Clinical and social characteristics and aggressive behavior of patients with long term of execution of compulsory measures of a medical nature. Obozrenie psikhiatrii i meditsinskoi 
psikhologii imeni V. M. Bekhtereva - The Bekhterev Review of Psychiatry and Medical Psychology, 2017, no. 1, pp. 45-52 (in Russian).

28. Shamova T. M., Karpovich-Misnik A. V. Personality characteristics of patients with multiple sclerosis in the projective Hand Test technique. Zhurnal Grodnenskogo gosudarstvennogo meditsinskogo universiteta - Journal of the Grodno State Medical University, 2007, no. 4 (20), pp. 80-82 (in Russian).

29. Belomestnova N. V. Opyt primeneniya metodiki the hand test v praktike sudebno-psikhologicheskoi ekspertizy v ugolovnom protsesse [Experience of using the Hand Test in forensic psychological examination in criminal trials]. Teoriya i praktika sudebnoi ekspertizy: mezhdunarodnyi opyt, problemy, perspektivy: sborniknauchnykh trudov I Mezhdunarodnogo foruma [Proc. the I International forum "Theory and practice of forensic examination: International experience, issues, and prospects"]. Moscow, Moscow University of the Ministry of internal Affairs of Russia Publ., 2017, pp. 415-420.

30. Khanin Yu. L. (ed.) Stress i trevoga $v$ sporte [Stress and anxiety in sports]. Moscow, Fizkul'tura i sport Publ., 1983. 288 p.

31. Rusalov V. M. Temperament v strukture individual'nosti cheloveka: differentsial'no-psikhofiziologicheskie ipsikhologicheskie issledovaniya [Temperament in the structure of human individuality: Differential psychophysiological and psychological studies]. Moscow, IP RAS Publ., 2012. 528 p.

32. Kurbatova T. N., Mulyar O. N. Proektivnaya metodika issledovaniya lichnosti "Hand-test" [The projective Hand Test technique for studying personality]. St. Petersburg, IMATON Publ., 2001. 64 p.

33. Witte A. V., Flöel A. Effects of COMT polymorphisms on brain function and behavior in health and disease. Brain Research Bulletin, 2012, V. 88, Issue 5, pp. 418-428. DOI: 10.1016/j.brainresbull.2011.11.012

34. Kukhtinskaya L.V., Zuraev A.V., Budevich V. A., Mosse I. B. Modern views on genetic determinants of human psycho-emotional stability. Molekulyarnaya iprikladnaya genetika - Molecular and Applied Genetics, 2016, V. 20, pp. 96-109 (in Russian).

35. Schneider M., Van der Linden M., Glaser B., Rizzi E., Dahoun S. P., Hinard C., Bartoloni L., Antonarakis S. E., Debbané M., Eliez S. Preliminary structure and predictive value of attenuated negative symptoms in 22q11.2 deletion syndrome. Psychiatry Research, 2012, V. 196, Issues 2-3, pp. 277-284. DOI: 10.1016/j.psychres.2011.08.017

36. Spasova A. P., Kurbatova I. V., Barysheva O. Yu., Tikhova G. P. The effect of polymorphism of cathechol-o-methyltrans-ferase gene on efficiency of analgesia in cancer patients. Rossiiskii zhurnal boli - Russian Journal of Pain, 2016, no. 3-4 (51), pp. 32-42 (in Russian).

37. Luchinkina A. I. Ethnic group, ethnicity, ethnic identity, ethnic individuation, and ethnic socialization in a multicultural society. In: Mezhkul'turnye 
vzaimodeistviya v polikul'turnom obshchestve [Intercultural interaction in a multicultural society]. Simferopol, IP Khoteeva L.V. Publ., 2016, pp. 43-63.

38. Kucher A. N. Gene-environmental interaction as the basis of health formation. Ekologicheskaya genetika - Ecological Genetics, 2017, V. 15, no. 4, pp. 19-32 (in Russian). DOI: 10.17816/ecogen15419-32

39. Atamanova I. V., Kozlova N. V., Bogomaz S. A., Zalevskii V. G., Neyaskina Yu. Yu. Specific character of person-environment interactions: A case of three Russian cities. Vestnik Tomskogo gosudarstvennogo universiteta. Filosofiya. Sotsiologiya. Politologiya - Tomsk State University Journal of Philosophy, Sociology and Political Science, 2018, no. 41, pp. 90-105 (in Russian).

40. Karabushchenko N. B., Khvorova E. M. Inter-ethnic characteristics of facial expression recognition. Vestnik Mininskogo universiteta - Vestnik of Minin University, 2017, no. 3 (20). DOI: 10.26795/2307-1281-2017-3-14 